\title{
A Review of Tropospheric Atmospheric Chemistry and Gas-Phase Chemical Mechanisms for Air Quality Modeling
}

\author{
William R. Stockwell ${ }^{1, *}$, Charlene V. Lawson ${ }^{1}$, Emily Saunders ${ }^{1}$ and Wendy S. Goliff ${ }^{2}$ \\ 1 Department of Chemistry, Howard University, 525 College Street, NW, Washington, DC 20059, \\ USA; E-Mails: Cvlawson@howard.edu (C.V.L.); Saunders1289@gmail.com (E.S.) \\ 2 Center for Environmental Research and Technology, University of California, Riverside, \\ CA 92521, USA; E-Mail: wendyg@engr.ucr.edu
}

* Author to whom correspondence should be addressed; E-Mail: William.R.Stockwell@gmail.com; Tel.: +1-202-806-6913; Fax: +1-202-806-5442.

Received: 25 October 2011; in revised form: 24 November 2011 / Accepted: 12 December 2011 / Published: 21 December 2011

\begin{abstract}
Gas-phase chemical mechanisms are vital components of prognostic air quality models. The mechanisms are incorporated into modules that are used to calculate the chemical sources and sinks of ozone and the precursors of particulates. Fifty years ago essential atmospheric chemical processes, such as the importance of the hydroxyl radical, were unknown and crude air quality models incorporated only a few parameterized reactions obtained by fitting observations. Over the years, chemical mechanisms for air quality modeling improved and became more detailed as more experimental data and more powerful computers became available. However it will not be possible to incorporate a detailed treatment of the chemistry for all known chemical constituents because there are thousands of organic compounds emitted into the atmosphere. Some simplified method of treating atmospheric organic chemistry is required to make air quality modeling computationally possible. The majority of the significant differences between air quality mechanisms are due to the differing methods of treating this organic chemistry. The purpose of this review is to present an overview of atmospheric chemistry that is incorporated into air quality mechanisms and to suggest areas in which more research is needed.
\end{abstract}

Keywords: atmospheric chemistry; troposphere; gas-phase; chemical mechanisms; ozone; nitrogen oxides; volatile organic compounds 


\section{Introduction}

The gas-phase chemistry of the polluted atmosphere determines the effect of emissions on the production of ozone $\left(\mathrm{O}_{3}\right)$, particulate matter, acids and other air pollutants. The chemical mechanism is developed from laboratory and field measurement data and consists of chemical species, reactions, rate constants and photochemical data (used to calculate photolysis frequencies). Nitrogen oxides, organic compounds and sulfur compounds are the key chemical compounds treated by air quality chemical mechanisms for modeling the polluted troposphere. The mechanism is translated into differential equations. The differential equations are coded into computer models that include numerical solvers that are used to simulate the chemical fate of air pollutants. Therefore mechanism developers must consider both chemistry and the limitations of computational resources.

The first goal of this paper is to present a brief overview of the approaches to create chemical mechanisms for modeling the chemistry of the polluted troposphere. The most significant differences between these air quality mechanisms are due to the differing methods of treating atmospheric organic chemistry. The three major types are surrogate mechanisms, mechanisms that aggregate organic compounds by chemical moiety and mechanisms that aggregate organic compounds by chemical species.

The second goal is to present a discussion of the behavior of the chemical mechanisms that are used for air quality modeling. Although previous studies of mechanism behavior have been published (e.g., [1-4]), very substantial changes have been made to the mechanisms over the last forty years due to growth in the chemical knowledge [5-8].

\section{Atmospheric Chemical Mechanisms for Modeling the Polluted Troposphere}

\subsection{Explicit Mechanisms}

Explicit mechanisms consist of explicit reactions for individual compounds. Atmospheric chemistry mechanisms usually include explicit mechanisms for the reactions of inorganic compounds, $\mathrm{O}_{3}$, nitric oxide $(\mathrm{NO})$, nitrogen dioxide $\left(\mathrm{NO}_{2}\right), \mathrm{NO}_{\mathrm{x}}\left(\mathrm{NO}+\mathrm{NO}_{2}\right)$, hydroxyl radical $(\mathrm{HO})^{\circ}$ ), the hydroperoxy radical $\left(\mathrm{HO}_{2}{ }^{\circ}\right)$ and sulfur dioxide $\left(\mathrm{SO}_{2}\right)$. A typical mechanism for tropospheric inorganic chemistry consists of fewer than 20 species in about 45 inorganic reactions.

The organic chemistry of the troposphere is much more complicated. There are thousands of compounds emitted from biological sources [9] and from anthropogenic sources [10]. The NCAR (National Center for Atmospheric Research) Master Mechanism includes about 800 organic species and 2200 reactions [11] while the Master Chemical Mechanism (MCM) mechanism consists of 2400 species, 7100 reactions for 124 emitted organic compounds [12]. A completely explicit chemical mechanism for the troposphere with all the chemical reactions of every compound could contain millions of reactions [13].

It is impossible to construct an atmospheric gas-phase mechanism from only published laboratory chemical kinetics data because there are significant gaps [14]. Many assumptions and estimates are made to fill in the gaps in order to construct an explicit atmospheric chemistry mechanism (and any other atmospheric chemical mechanism). Some of the largest gaps exist with radical-radical reactions and the oxidation schemes for aromatic and biogenically emitted compounds. For example, the MCM includes detail that exceeds available laboratory data. Many of the mechanism's organic degradation 
schemes were developed according to theoretical methodologies such as structure activity relationships (SARs). The MCM has been tested against environmental chamber experiments and field data. This testing has shown that the mechanism can simulate these measurements reasonably well.

Explicit mechanisms are mainly used in box models for chemical research. They are not very practical for 3-D air quality models because of their extensive computational requirements. A reduced version of the MCM has been developed and used for 3-D air quality modeling $[15,16]$. The practical problem is due to computational issues involving three-dimensional Eulerian regional air quality models. These models consist of $10^{5}$ or more grid boxes [17]. Every chemical species that exists long enough to be transported by atmospheric motions is a prognostic variable that must be calculated explicitly. Each prognostic variable adds one ordinary differential equation that must be solved and an additional storage location for every grid box. Increasing the number of chemical species also increases significantly the computational demands for transport calculations [18]. A complete, explicit, gas-phase chemical mechanism in Eulerian regional air quality models is not practical with present computer technology. Therefore chemical mechanisms must be condensed to limit the size of the mechanism to no more than a few hundred reactions and near one hundred model chemical species [19]. Classes of simplified chemical mechanisms for air quality modeling include surrogate mechanisms and aggregated mechanisms as discussed in the next sections.

\subsection{Surrogate Mechanisms}

A surrogate mechanism is a mechanism that is somewhere between explicit and aggregated mechanisms. A surrogate mechanism uses the explicit chemistry of a few selected organic species to represent the atmospheric chemistry of all volatile organic compounds (VOC). One of the earliest was the Empirical Kinetics Modeling Approach (EKMA) developed by Dimitriades and Dodge [20]. The EKMA mechanism represented atmospheric organic chemistry with butane and propene as surrogate species. The combination of a less reactive alkane and a more reactive alkene allowed representation of a wide range of the overall reactivity of a mixture of VOCs.

The EKMA mechanism was implemented in a box model for most applications. The model was used to simulate the air quality of a particular site. An estimate of an appropriate mixture of butane and propene was determined from the site's emissions inventory. Then the box model was used to make a series of simulations with various initial concentrations and/or emissions of $\mathrm{NO}_{\mathrm{x}}$ and VOC. Maximum $\mathrm{O}_{3}$ concentrations were plotted as contour diagrams as functions of the initial $\mathrm{NO}_{\mathrm{x}}$ and VOC concentrations; these diagrams are known as an ozone isopleths. The EKMA ozone isopleths were used for developing air quality control strategies and ozone isopleths calculated by more rigorous methods. Figure 1 shows a sample ozone isopleth generated with the RADM2 (Regional Acid Deposition Mechanism, version 2) mechanism [21]. For example, the figure shows that when $\mathrm{NO}_{\mathrm{x}}$ concentrations are below $50 \mathrm{ppb}(\mathrm{ppbN})$ that further reductions in $\mathrm{NO}_{\mathrm{x}}$ would not be effective in reducing the $\mathrm{O}_{3}$ concentration. However at this level of $\mathrm{NO}_{x}$ the $\mathrm{O}_{3}$ concentrations are very sensitive to the VOC concentration. The figure also shows that for greater $\mathrm{NO}_{\mathrm{x}}$ concentrations that reductions in either the initial $\mathrm{NO}_{\mathrm{x}}$ or VOC concentration may lead to less $\mathrm{O}_{3}$. 
Figure 1. Typical ozone isopleth generated with the RADM mechanism [21].

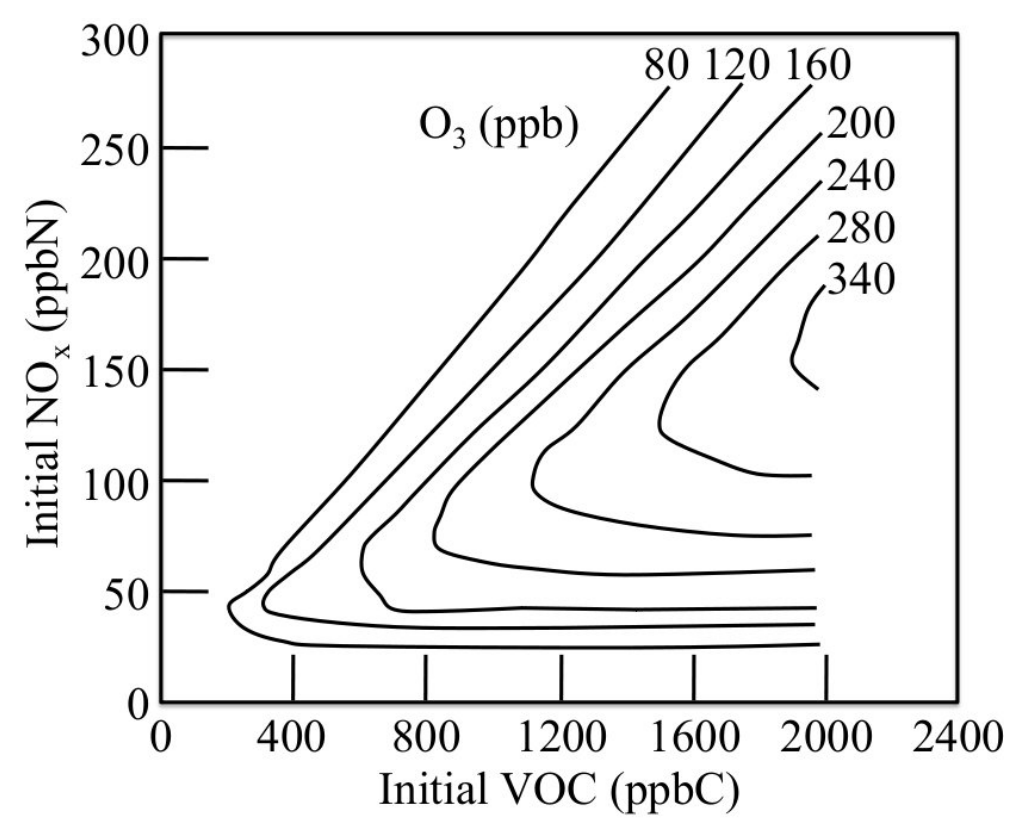

\subsection{Aggregated Chemical Mechanisms}

Aggregated mechanisms use model species to represent the reactions of entire classes of organic compounds. One major method used for chemical aggregation is to aggregate by chemical moiety. The early Carbon Bond Mechanism was an extremely innovative approach to the atmospheric organic chemistry of the polluted urban atmosphere $[22,23]$. Carbon Bond is a mechanism that aggregates organic compounds into model species according to constituent molecular groups. In the Carbon Bond Mechanism the model species represent the concentrations of constituent groups regardless of the molecule to which they are attached. For example, the Carbon Bond mechanism included model species such as PAR (alkane carbon atoms), OLE (double bonded carbon atoms), ARO (aromatic rings) and CAR (carbonyl group). Suppose there was a mixture of $1.0 \mathrm{ppmV}$ of butane $\left(\mathrm{CH}_{3} \mathrm{CH}_{2} \mathrm{CH}_{2} \mathrm{CH}_{3}\right)$ and $1.0 \mathrm{ppmV}$ of propene $\left(\mathrm{CH}_{3} \mathrm{HC}=\mathrm{CH}_{2}\right)$. These chemical species would be grouped as $4.0 \mathrm{ppmC}$ PAR from the butane and additional $1.0 \mathrm{ppmC}$ PAR and 1.0 ppmC OLE from the propene for a total of 5.0 ppmC PAR and 1.0 ppmC of OLE. A key advantage of the original Carbon Bond approach was its relative ease in grouping emissions into species, the conservation of carbon atoms and the relatively low number of chemical species required to represent organic chemistry.

The lower number of species and its relatively small size resulted in reduced the computational resources needed to run models with the mechanism. The original Carbon Bond approach has declined as the mechanism has been developed and the approach is increasingly the same as an aggregated molecule mechanism because constituent groups on the same molecule and the total molecular weight strongly affect atmospheric chemistry [24,25]. However it is surprising that relatively minor modifications to recent versions of the Carbon Bond Mechanism allow it to estimate secondary organic aerosol concentrations that are very similar to those of more complex mechanisms [26].

A more obvious method of aggregating chemical species into model species is aggregation by molecule. Moles of similar chemical compounds are aggregated into a grouped model species. For example, the model species "ALD" might represent all aldehydes while "PRO" might represent 
propane and all less reactive alkanes according to an aggregation by molecule approach. In some schemes weighting factors to account for chemical reactivity or carbon mass may be applied in the aggregation scheme (e.g., [27]). The series of mechanisms produced by the Statewide Air Pollution Research Center (SAPRC) at the University of California, Riverside, is an important example of aggregated chemical mechanisms. This series of mechanisms includes SAPRC-90, SAPRC-99 and SAPRC-07 air quality mechanisms [28-30]. Versions of SAPRC can represent about 400 categories of VOCs while condensed versions with less complexity in the VOC chemistry has been created for urban and regional air quality models. SAPRC was originally designed for the treatment of highly polluted urban atmospheres and it has evolved to treat regional chemistry as well.

Some mechanisms were developed originally for regional applications and therefore needed to account for a wider range of pollutant concentrations. Regional mechanisms are designed to provide predictions for urban regions and for the regional scale. The regional scale includes locations where $\mathrm{NO}_{\mathrm{x}}$ concentrations are lower and where the reactivity of more slowly reacting organic compounds is more important than in urban areas. One widely used example is the Regional Atmospheric Chemical Mechanism, version 1 (RACM1), the Regional Atmospheric Chemical Mechanism, version 2 (RACM2) and their predecessors aggregate organic compounds by molecule [21,27,31,32]. RACM2 currently has a total of 118 model chemical species with a total of 356 reactions.

\section{The Chemistry of Air Pollution}

\subsection{Methods and Models}

Simulations were made to illustrate important chemical processes relevant to air quality in this study. They were performed using a box modeling system described previously with the RACM2 mechanism [31,33]. All simulations were made with gas-phase chemistry for clear sky and constant meteorological conditions. Physical loss processes, such as deposition, were not included. The first set included simulations of simple mixtures without emissions. A second set of simulations were made for a polluted urban case was simulated that included emissions.

The rate of photolysis of $\mathrm{O}_{3}$ and any other compound is the product of the compound's concentration and the reaction's photolysis frequency, J. The photolysis frequency is the integral of the product of the wavelength dependent, $\lambda$, spherically integrated actinic flux, $I(\lambda)$, the absorption cross-section, $\sigma(\lambda)$, and the quantum yield, $\varphi(\lambda)$, (probability that molecule will react after absorbing a photon of wavelength $\lambda$ ), Equation 1.

$$
J=\int I(\lambda) \sigma(\lambda) \varphi(\lambda) d \lambda
$$

The photolysis rate coefficients for the photochemical reactions were calculated using the delta-Eddington radiative transfer model [34]. The RACM2 mechanism includes 33 photolysis reactions. The absorption cross-sections and quantum yields have been revised to be consistent with recent recommendations [7,8]. Aldehydes that have photolysis reactions included in RACM2 are formaldehyde, acetaldehyde, a higher aldehyde, unsaturated aldehyde (formed from aromatic oxidation) and benzaldehyde. Two photolysis reactions are included for peroxyacetyl nitrate. The ketones with photolysis reactions in RACM2 are acetone, methethylketone, methylvinylketone and a 
higher ketone. The product yields glyoxal, methyl glyoxal and higher dicarbonyl species have been revised for RACM2 based on the recent data.

All simulations discussed below were made for the surface level with the conditions given in Table 1. Simulations were performed for an $\mathrm{O}_{3}$ only system, with variations upon the addition of $\mathrm{NO}_{\mathrm{x}}$, and VOCs. Specific cases included adjusting the VOC to $\mathrm{NO}_{\mathrm{x}}$ ratio by doubling and halving ethene concentrations, Table 2. Simulations were made with the RACM2 mechanism with initial conditions and emissions for a polluted urban atmosphere, Tables 1 and 3. Note that in Table 3 for temperatures of $298 \mathrm{~K}$ and pressures of 1 atmosphere, "Slow Alkanes" in RACM2 are defined to have HO" rate constants less than $3.4 \times 10^{-12} \mathrm{~cm}^{3} \mathrm{~s}^{-1}$, "Medium Alkanes" have HO' rate constants between $3.4 \times 10^{-12}$ and $6.8 \times 10^{-12} \mathrm{~cm}^{3} \mathrm{~s}^{-1}$ and "Fast Alkanes" have $\mathrm{HO}^{\circ}$ rate constants greater than $6.8 \times 10^{-12} \mathrm{~cm}^{3} \mathrm{~s}^{-1}$. "Internal Alkenes" have double bond in an internal position and "Terminal Alkenes" have a double bond in the terminal position.

These simulations were repeated for a range of temperatures 296, 298 and 300 and these are discussed in section "3.8. The Effect of Temperature on Ozone Formation".

Table 1. Conditions used for all simulations.

\begin{tabular}{lc}
\hline \multicolumn{1}{c}{ Initial Condition } & Value \\
\hline Start-Time & $6: 00$ \\
Duration & $48 \mathrm{~h}$ \\
Temperature & $298 \mathrm{~K}$ \\
Pressure & $1013.25 \mathrm{mbar}$ \\
$\mathrm{H}_{2} \mathrm{O}$ Mixing Ratio & $15,500 \mathrm{ppm}$ \\
$\mathrm{H} 2$ Mixing Ratio & $550 \mathrm{ppm}$ \\
Date for photolysis calculation & $21 \mathrm{June}$ \\
Latitude & $40^{\circ}$ \\
\hline
\end{tabular}

Table 2. Simplified simulations made to illustrate atmospheric chemistry mechanisms.

\begin{tabular}{lccc}
\hline Case & $\mathbf{O}_{\mathbf{3}} \mathbf{( p p b )}$ & $\mathbf{N O}_{\mathbf{2}}(\mathbf{p p b})$ & Ethene $(\mathbf{p p b})$ \\
\hline $\mathrm{O}_{3}$ only & 30 & 0 & 0 \\
$\mathrm{NO}_{2}$ only & 0 & 30 & 0 \\
Ethene $4 *$ & 30 & 2.5 & 5 \\
Ethene $8 *$ & 30 & 2.5 & 10 \\
Ethene $16 *$ & 30 & 2.5 & 20 \\
\hline
\end{tabular}

$* \mathrm{VOC} / \mathrm{NO}_{\mathrm{x}}$ ratio. 
Table 3. Initial concentrations and emissions used for the simulation of a polluted urban atmosphere. The initial VOC to $\mathrm{NO}_{\mathrm{x}}$ ratio is 19.

\begin{tabular}{|c|c|c|}
\hline Species & $\begin{array}{c}\text { Initial Concentration } \\
(\mathbf{p p b})\end{array}$ & $\begin{array}{l}\text { Emission Rate } \\
\left(\text { ppb } \min ^{-1}\right)\end{array}$ \\
\hline \multicolumn{3}{|l|}{ Inorganic } \\
\hline Ozone & 30 & --- \\
\hline Nitric Oxide & 8. & $2.77 \times 10^{-3}$ \\
\hline Nitrogen Dioxide & 2 & $5.43 \times 10^{-4}$ \\
\hline Sulfur Dioxide & 30 & $2.94 \times 10^{-3}$ \\
\hline Carbon Monoxide & 1000 & $4.53 \times 10^{-3}$ \\
\hline Hydrogen & 550 & --- \\
\hline \multicolumn{3}{|l|}{ Organic } \\
\hline Methane & 1800 & \\
\hline Ethane & 3 & $8.03 \times 10^{-5}$ \\
\hline Slow Reacting Alkanes & 10 & $1.86 \times 10^{-3}$ \\
\hline Medium Reacting Alkanes & 2.5 & $6.81 \times 10^{-4}$ \\
\hline Fast Reacting Alkanes & 1.5 & $5.10 \times 10^{-4}$ \\
\hline Ethene & 2.0 & $6.78 \times 10^{-4}$ \\
\hline Internal Alkenes & 1.0 & $3.47 \times 10^{-4}$ \\
\hline Terminal Alkenes & 2.0 & $6.94 \times 10^{-4}$ \\
\hline Dienes & 0.5 & $1.74 \times 10^{-4}$ \\
\hline Benzene & 0.9 & $1.06 \times 10^{-4}$ \\
\hline Toluene & 2.0 & $6.05 \times 10^{-4}$ \\
\hline Xylene & 2.0 & $6.94 \times 10^{-4}$ \\
\hline$o$-Xylene & 1.0 & $3.44 \times 10^{-4}$ \\
\hline Methanol & 0.1 & --- \\
\hline Ethanol & 0.1 & --- \\
\hline Higher Alcohols & 0.1 & --- \\
\hline Formaldehyde & 2.5 & $3.21 \times 10^{-5}$ \\
\hline Acetylene & 2.0 & $1.58 \times 10^{-4}$ \\
\hline Acetaldehyde & 1.0 & $3.15 \times 10^{-5}$ \\
\hline Higher Aldehyde & 0.5 & --- \\
\hline Acetone & 0.3 & --- \\
\hline Methyl Ethyl Ketone & 2.0 & --- \\
\hline Higher Ketone & 2.0 & --- \\
\hline Ethylene Glycol & 0.2 & --- \\
\hline Methylglyoxal & 0.05 & --- \\
\hline Methacrolein & 0.1 & --- \\
\hline Methyl Vinyl Ketone & 0.1 & --- \\
\hline Isoprene & 3.4 & $1.18 \times 10^{-3}$ \\
\hline$\alpha$-Pinenes & 1.0 & $3.47 \times 10^{-4}$ \\
\hline$d$-Limonene & 1.0 & $3.47 \times 10^{-4}$ \\
\hline
\end{tabular}




\subsection{The Inorganic Chemistry of Ozone Production}

Ozone is a constituent of the natural troposphere due primarily to its production in the stratosphere [35]. A fraction of stratospheric $\mathrm{O}_{3}$ passes to the troposphere (transported by folding events, for example). Some of the $\mathrm{O}_{3}$ is lost through photochemistry and other reactions and it is deposited to the Earth's surface. Excited oxygen atoms, $\mathrm{O}\left({ }^{1} \mathrm{D}\right)$, are produced by the photolysis of $\mathrm{O}_{3}$.

$$
\mathrm{O}_{3}+\mathrm{hv} \rightarrow \mathrm{O}\left({ }^{1} \mathrm{D}\right)+\mathrm{O}_{2}
$$

The majority of the $\mathrm{O}\left({ }^{1} \mathrm{D}\right)$ are quenched to yield ground state oxygen atoms $\left(\mathrm{O}\left({ }^{3} \mathrm{P}\right)\right)$.

$$
\begin{aligned}
& \mathrm{O}\left({ }^{1} \mathrm{D}\right)+\mathrm{N}_{2} \rightarrow \mathrm{O}\left({ }^{3} \mathrm{P}\right)+\mathrm{N}_{2} \\
& \mathrm{O}\left({ }^{1} \mathrm{D}\right)+\mathrm{O}_{2} \rightarrow \mathrm{O}\left({ }^{3} \mathrm{P}\right)+\mathrm{O}_{2}
\end{aligned}
$$

The $\mathrm{O}\left({ }^{3} \mathrm{P}\right)$ react with oxygen molecules to form $\mathrm{O}_{3}$, Reaction 5 .

$$
\mathrm{O}\left({ }^{3} \mathrm{P}\right)+\mathrm{O}_{2}+\mathrm{M} \rightarrow \mathrm{O}_{3}+\mathrm{M}
$$

In Reaction 5, M represents molecular nitrogen, oxygen or other gaseous species that transfers excess energy from the transition state to stabilize the potential $\mathrm{O}_{3}$ molecule. Almost all of the $\mathrm{O}\left({ }^{3} \mathrm{P}\right)$ in the troposphere react with oxygen molecules (except in highly polluted emission plumes) because Reaction 5 is very fast in the troposphere due to its high oxygen concentrations and high pressure.

Although most of the $O\left({ }^{1} \mathrm{D}\right)$ are quenched to reform $O\left({ }^{3} \mathrm{P}\right)$ a fraction of the $\mathrm{O}\left({ }^{1} \mathrm{D}\right)$ react with water vapor to form $\mathrm{HO}^{\circ}$. The $\mathrm{HO}^{\circ}$ radical is the most important oxidant found in the troposphere.

$$
\mathrm{O}\left({ }^{1} \mathrm{D}\right)+\mathrm{H}_{2} \mathrm{O} \rightarrow 2 \mathrm{HO}^{\bullet}
$$

The effects of these reactions are illustrated by a simulation of a mixture of $\mathrm{O}_{3}$ in background air without $\mathrm{NO}_{\mathrm{x}}$ or reactive VOC. In the simulation $\mathrm{O}_{3}$ is photolyzed during the daytime to produce $\mathrm{O}\left({ }^{1} \mathrm{D}\right)$, Figure 2 . Note the extremely low mixing ratios of the $\mathrm{O}\left({ }^{1} \mathrm{D}\right)$.

Figure 2. Excited oxygen atom $\left(\mathrm{O}\left({ }^{1} \mathrm{D}\right)\right)$ for the $\mathrm{O}_{3}$ only case.

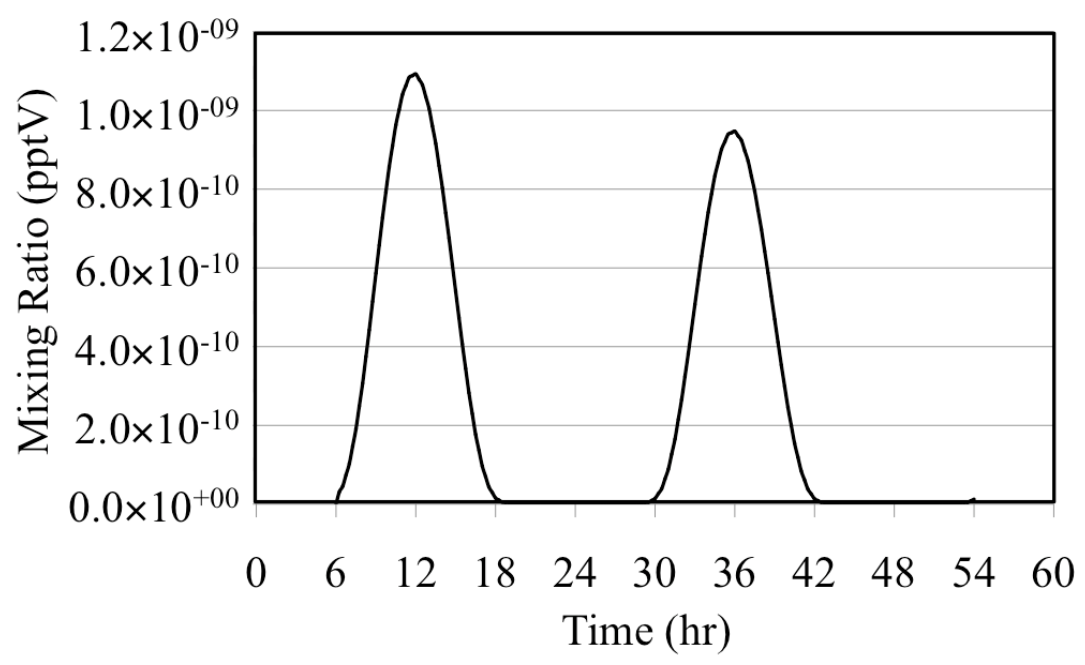


The mixing ratio of the $\mathrm{O}\left({ }^{1} \mathrm{D}\right)$ follows the solar zenith angle with the peak mixing ratio occurring at the local solar noon due to its photochemical production. The $\mathrm{HO}^{\bullet}$ reacts rapidly with $\mathrm{O}_{3}$ to produce $\mathrm{HO}_{2}^{\circ}$, Figure 3 .

$$
\mathrm{HO}^{\bullet}+\mathrm{O}_{3} \rightarrow \mathrm{HO}_{2}^{\bullet}+\mathrm{O}_{2}
$$

Figure 3. $\mathrm{HO}^{\circ}$ and $\mathrm{HO}_{2}{ }^{\circ}$ radicals for the $\mathrm{O}_{3}$ only case.

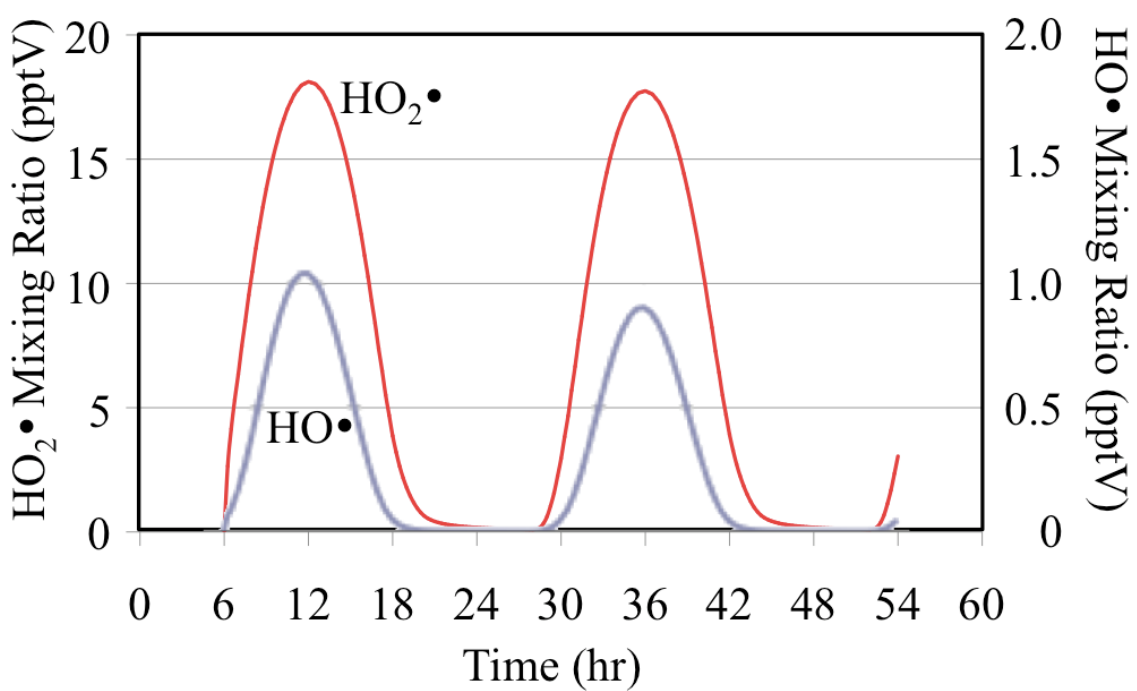

The net effect of the photolysis of $\mathrm{O}_{3}$ and its reactions with $\mathrm{HO}^{\circ}$ and $\mathrm{HO}_{2}{ }^{\circ}$ is to reduce $\mathrm{O}_{3}$ mixing ratios on the second day, Figure 4. On the second day the lower mixing ratios of $\mathrm{O}_{3}$ reduce the formation rate of $\mathrm{O}\left({ }^{1} \mathrm{D}\right)$ from photolysis and therefore the $\mathrm{O}\left({ }^{1} \mathrm{D}\right)$ mixing ratios are lower, Figure 2 . The lower second day $\mathrm{O}\left({ }^{1} \mathrm{D}\right)$ mixing ratios reduce the mixing ratios of the $\mathrm{HO}$ radical, Figure 3 . The $\mathrm{HO}_{2}{ }^{\circ}$ mixing ratios are lower on the second day but the relative reduction is not as great for $\mathrm{HO}_{2}{ }^{\circ}$ as it is for $\mathrm{O}\left({ }^{1} \mathrm{D}\right)$ and $\mathrm{HO}^{\circ}$.

Figure 4. Ozone mixing ratios for the $\mathrm{O}_{3}$ only case.

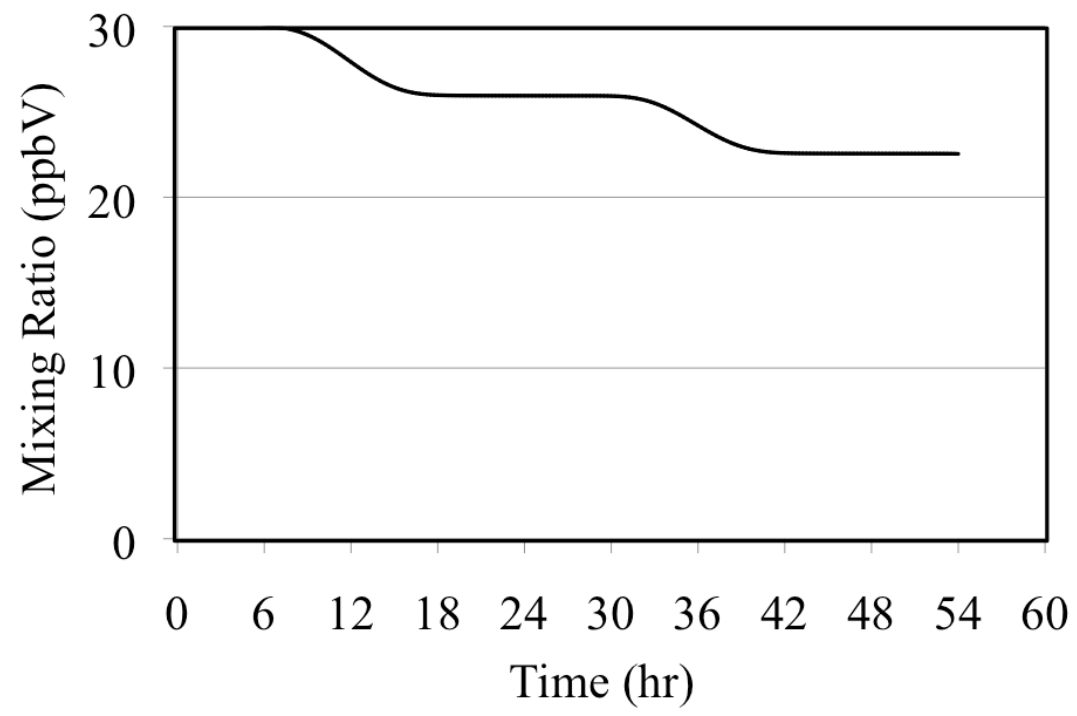


The photolysis of $\mathrm{NO}_{2}$ is the major source of $\mathrm{O}\left({ }^{3} \mathrm{P}\right)$. These react to produce tropospheric $\mathrm{O}_{3}$ through Reaction 5.

$$
\mathrm{NO}_{2}+\mathrm{h} v \rightarrow \mathrm{NO}+\mathrm{O}\left({ }^{3} \mathrm{P}\right)
$$

Reaction 9 is a major sink reaction for $\mathrm{O}_{3}$ and $\mathrm{NO}$.

$$
\mathrm{O}_{3}+\mathrm{NO} \rightarrow \mathrm{NO}_{2}+\mathrm{O}_{2}
$$

Reactions 8 and 9 play a major role in controlling tropospheric $\mathrm{O}_{3}$ concentrations. As stated above, Reaction 5 is very fast in the troposphere so all of the $\mathrm{O}\left({ }^{3} \mathrm{P}\right)$ produced by $\mathrm{NO}_{2}$ photolysis can be assumed to react to produce $\mathrm{O}_{3}$. If Reactions 8 and 9 are in equilibrium then the $\mathrm{O}_{3}$ concentration is given by the $\mathrm{O}_{3}$ photostationary state approximation (PSSA), Equation 10 [36].

$$
\left[\mathrm{O}_{3}\right]=\frac{J_{\mathrm{NO}_{2}}\left[\mathrm{NO}_{2}\right]}{k[\mathrm{NO}]}
$$

The brackets indicate chemical concentrations for the respective species, $J_{\mathrm{NO} 2}$ is the solar radiation dependant photolysis frequency of Reaction 8 and $k$ is the rate constant of Reaction 9. The value of $J_{\mathrm{NO} 2}$ depends on the intensity of solar radiation and for this reason $J_{\mathrm{NO} 2}$ follows the solar diurnal cycle. According to t34he PSSA the $\mathrm{O}_{3}$ concentration follows the solar diurnal cycle if there is no carbon monoxide or reactive organic compounds present, Figure 5.

Figure 5. Ozone mixing ratios are shown for the $\mathrm{NO}_{2}$ only case.

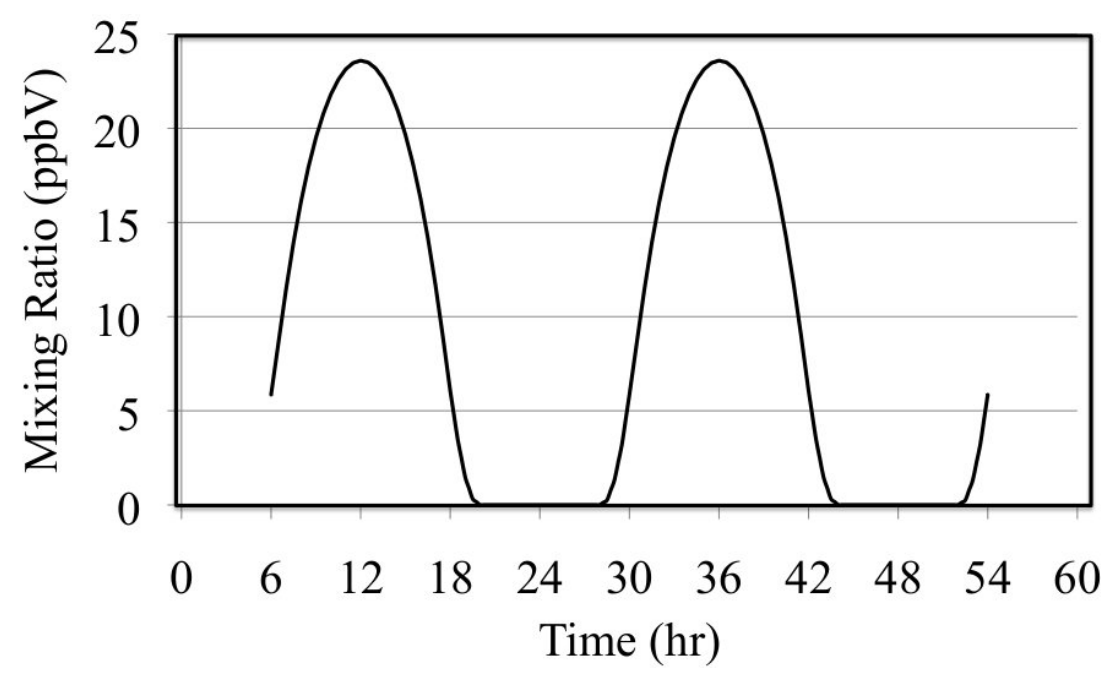

\subsection{The Effects of Hydrocarbons on Ozone Production}

Real tropospheric $\mathrm{O}_{3}$ production occurs when additional reactions involving $\mathrm{CO}$, VOC, nitrogen oxides, $\mathrm{HO}^{\circ}, \mathrm{HO}_{2}{ }^{\circ}$ and organic peroxy radicals $\left(\mathrm{RO}_{2}{ }^{\circ}\right.$ and $\left.\mathrm{RCO}_{3}{ }^{\circ}\right)$, increase the $\mathrm{NO}_{2}$ to $\mathrm{NO}$ concentration ratio $[3,36]$. The reaction of $\mathrm{HO}^{\circ}$ radicals with $\mathrm{CO}$ and $\mathrm{VOC}$ produce peroxy radicals that convert $\mathrm{NO}$ to $\mathrm{NO}_{2}$. Reaction 11 illustrates the formation of the hydroperoxy radical.

$$
\mathrm{HO}^{\bullet}+\mathrm{CO}\left(+\mathrm{O}_{2}\right) \rightarrow \mathrm{HO}_{2}{ }^{\circ}+\mathrm{CO}_{2}
$$

The formation of the hydroperoxy radical provides a key pathway to the "extra" conversions of NO to $\mathrm{NO}_{2}$ that are needed for $\mathrm{O}_{3}$ production. 


$$
\mathrm{HO}_{2}{ }^{\bullet}+\mathrm{NO} \rightarrow \mathrm{HO}^{\bullet}+\mathrm{NO}_{2}
$$

There are many VOC compounds that are important for atmospheric chemistry $[3,35]$. For example, alkanes are hydrocarbons (containing only hydrogen and carbon atoms) and the atoms are bonded together with only single bonds. Methane $\left(\mathrm{CH}_{4}\right)$ is the simplest example of an alkane. Other examples include ethane $\left(\mathrm{CH}_{3} \mathrm{CH}_{3}\right)$, propane $\left(\mathrm{CH}_{3} \mathrm{CH}_{2} \mathrm{CH}_{3}\right)$, n-butane $\left(\mathrm{CH}_{3} \mathrm{CH}_{2} \mathrm{CH}_{2} \mathrm{CH}_{3}\right)$ and tertiary-butane $\left(\mathrm{CH}_{3}\right)_{3} \mathrm{CH}$. The hydrogen atoms on the $\mathrm{CH}_{3}, \mathrm{CH}_{2}$ and $\mathrm{CH}$ groups are called primary, secondary and tertiary hydrogen atoms, respectively.

Alkanes react with $\mathrm{HO}^{\circ}$ through abstraction of a hydrogen atom, leading to the production of hydroperoxy radicals and organic peroxy radicals [3]. Methane reacts with $\mathrm{HO}^{\circ}$ and it abstracts a hydrogen atom to form a methyl radical and water.

$$
\mathrm{HO}^{\bullet}+\mathrm{CH}_{4} \rightarrow \mathrm{CH}_{3}^{\cdot}+\mathrm{H}_{2} \mathrm{O}
$$

The methyl radical rapidly reacts with oxygen to produce a methyl peroxy radical.

$$
\mathrm{CH}_{3}{ }^{\circ}+\mathrm{O}_{2} \rightarrow \mathrm{CH}_{3} \mathrm{O}_{2}^{\cdot}
$$

The methyl peroxy radical reacts with $\mathrm{NO}$ to convert it to $\mathrm{NO}_{2}$.

$$
\mathrm{CH}_{3} \mathrm{O}_{2}^{\cdot}+\mathrm{NO} \rightarrow \mathrm{CH}_{3} \mathrm{O}^{\bullet}+\mathrm{NO}_{2}
$$

The methoxy radical $\mathrm{CH}_{3} \mathrm{O}^{\circ}$, reacts with oxygen to form formaldehyde and a hydroperoxy radical.

$$
\mathrm{CH}_{3} \mathrm{O}^{\bullet}+\mathrm{O}_{2} \rightarrow \mathrm{CH}_{2} \mathrm{O}+\mathrm{HO}_{2}^{\cdot}
$$

The $\mathrm{HO}_{2}{ }^{\circ}$ radical reacts with $\mathrm{NO}$ to make one more $\mathrm{NO}$ to $\mathrm{NO}_{2}$ conversion through Reaction 12. The net effect of the initial reaction of the $\mathrm{HO}^{\circ}$ radical with an alkane is to produce several $\mathrm{NO}$ to $\mathrm{NO}_{2}$ conversions and these conversions increase the $\left[\mathrm{NO}_{2}\right] /[\mathrm{NO}]$ ratio by Equation 10 , and so the concentration of $\mathrm{O}_{3}$ increases.

For alkanes with more complicated structures $\mathrm{HO}^{\bullet}$ may abstract any of an alkane's hydrogen atoms but both reactivity differences between the different kinds of hydrogen atoms and the number of the kinds of hydrogen atoms affect the quantity of the different possible products. For alkanes, tertiary hydrogen atoms are more reactive than secondary and secondary hydrogen atoms are more reactive than primary hydrogen atoms. Reactions 17 and 18 illustrate the two possible channels for the reaction of $n$-butane with $\mathrm{HO}^{\circ}$.

Primary Hydrogen Abstraction

$$
\mathrm{CH}_{3} \mathrm{CH}_{2} \mathrm{CH}_{2} \mathrm{CH}_{3}+\mathrm{HO}^{\bullet} \rightarrow \mathrm{CH}_{3} \mathrm{CH}_{2} \mathrm{CH}_{2} \mathrm{CH}_{2}{ }^{\bullet}+\mathrm{H}_{2} \mathrm{O}
$$

Secondary Hydrogen Abstraction

$$
\mathrm{CH}_{3} \mathrm{CH}_{2} \mathrm{CH}_{2} \mathrm{CH}_{3}+\mathrm{HO}^{\bullet} \rightarrow \mathrm{CH}_{3}\left(\mathrm{C}^{*} \mathrm{H}\right) \mathrm{CH}_{2} \mathrm{CH}_{3}+\mathrm{H}_{2} \mathrm{O}
$$

The two different radicals react with molecular oxygen to produce a primary organic peroxy radical, Reaction 19 and a secondary organic peroxy radical, Reaction 20.

$$
\begin{aligned}
& \mathrm{CH}_{3} \mathrm{CH}_{2} \mathrm{CH}_{2} \mathrm{CH}_{2}{ }^{\circ}+\mathrm{O}_{2} \rightarrow \mathrm{CH}_{3} \mathrm{CH}_{2} \mathrm{CH}_{2} \mathrm{CH}_{2} \mathrm{O}_{2}{ }^{-} \\
& \mathrm{CH}_{3}\left(\mathrm{C}^{\cdot} \mathrm{H}\right) \mathrm{CH}_{2} \mathrm{CH}_{3}+\mathrm{O}_{2} \rightarrow \mathrm{CH}_{3} \mathrm{CHO}_{2}{ }^{\circ} \mathrm{CH}_{2} \mathrm{CH}_{3}
\end{aligned}
$$


The primary organic peroxy radical reacts with $\mathrm{NO}$ to produce a primary alkoxy radical that reacts with oxygen to yield $n$-butanal, $\mathrm{CH}_{3} \mathrm{CH}_{2} \mathrm{CH}_{2} \mathrm{CHO}$ and a $\mathrm{HO}_{2}{ }^{\circ}$ radical.

$$
\begin{gathered}
\mathrm{CH}_{3} \mathrm{CH}_{2} \mathrm{CH}_{2} \mathrm{CH}_{2} \mathrm{O}_{2}^{-}+\mathrm{NO} \rightarrow \mathrm{CH}_{3} \mathrm{CH}_{2} \mathrm{CH}_{2} \mathrm{CH}_{2} \mathrm{O}^{\bullet}+\mathrm{NO}_{2} \\
\mathrm{CH}_{3} \mathrm{CH}_{2} \mathrm{CH}_{2} \mathrm{CH}_{2} \mathrm{O}^{\bullet}+\mathrm{O}_{2} \rightarrow \mathrm{CH}_{3} \mathrm{CH}_{2} \mathrm{CH}_{2} \mathrm{CHO}+\mathrm{HO}_{2}^{\cdot}
\end{gathered}
$$

The secondary organic peroxy radical reacts with NO to produce a secondary alkoxy radical that reacts with oxygen to yield methyl ethyl ketone, $\mathrm{CH}_{3}(\mathrm{CO}) \mathrm{CH}_{2} \mathrm{CH}_{3}$ and a $\mathrm{HO}_{2}{ }^{\circ}$ radical.

$$
\begin{gathered}
\mathrm{CH}_{3}\left(\mathrm{CHO}_{2}^{\circ}\right) \mathrm{CH}_{2} \mathrm{CH}_{3}+\mathrm{NO} \rightarrow \mathrm{CH}_{3}\left(\mathrm{CHO}^{\circ}\right) \mathrm{CH}_{2} \mathrm{CH}_{3}+\mathrm{NO}_{2} \\
\mathrm{CH}_{3}\left(\mathrm{CHO}^{\circ}\right) \mathrm{CH}_{2} \mathrm{CH}_{3}+\mathrm{O}_{2} \rightarrow \mathrm{CH}_{3}(\mathrm{CO}) \mathrm{CH}_{2} \mathrm{CH}_{3}+\mathrm{HO}_{2}{ }^{\circ}
\end{gathered}
$$

Alkenes are hydrocarbons with at least one double bond. Alkenes lead to greater $\mathrm{O}_{3}$ production than alkanes because of their higher rate constant for the reaction with $\mathrm{HO}^{\circ}$. Ethene, $\mathrm{CH}_{2}=\mathrm{CH}_{2}$, is the simplest example of an alkene while propene, $\mathrm{CH}_{3} \mathrm{CH}=\mathrm{CH}_{2}$, is the next higher compound in the series. An alkene's rate constant for its reactions with $\mathrm{HO}^{\circ}, \mathrm{O}_{3}$ and the resulting reaction products, depends very strongly on the location and number of double bonds in the alkene. For example, butene may have the double bond located at the end of the molecule, $\mathrm{CH}_{2}=\mathrm{CHCH}_{2} \mathrm{CH}_{3}$ (1-butene), or within the molecule, $\mathrm{CH}_{3} \mathrm{CH}=\mathrm{CHCH}_{3}$ (2-butene). In this case the rate constant for the reaction of $\mathrm{HO}^{\circ}$ with 2-butene is greater than its reaction with 1-butene.

In contrast to alkanes, the $\mathrm{HO}^{\circ}$ reacts with alkenes through addition to either carbon atom of the double bond. For example, propene adds $\mathrm{HO}^{\circ}$ to produce a radical that adds an oxygen molecule to form a peroxy radical $\left(\mathrm{CH}_{3}(\mathrm{HCOH}) \mathrm{CH}_{2} \mathrm{O}_{2}{ }^{\circ}\right)$, Reactions 25 and 26.

$$
\begin{gathered}
\mathrm{CH}_{3} \mathrm{HC}=\mathrm{CH}_{2}+\mathrm{HO}^{\circ} \rightarrow \mathrm{CH}_{3}(\mathrm{HCOH}) \mathrm{CH}_{2}{ }^{\cdot} \\
\mathrm{CH}_{3}(\mathrm{HCOH}) \mathrm{CH}_{2}{ }^{\circ}+\mathrm{O}_{2} \rightarrow \mathrm{CH}_{3}(\mathrm{HCOH}) \mathrm{CH}_{2} \mathrm{O}_{2}{ }^{\circ}
\end{gathered}
$$

The $\mathrm{CH}_{3}(\mathrm{HCOH}) \mathrm{CH}_{2} \mathrm{O}_{2}{ }^{*}$ radical reacts with $\mathrm{NO}$ to produce $\mathrm{NO}_{2}$ and a hydroxy-carbonyl compound, Reactions 27 and 28.

$$
\begin{gathered}
\mathrm{CH}_{3}(\mathrm{HCOH}) \mathrm{CH}_{2} \mathrm{O}_{2}{ }^{\circ}+\mathrm{NO} \rightarrow \mathrm{CH}_{3}(\mathrm{HCOH}) \mathrm{CH}_{2} \mathrm{O}^{\bullet}+\mathrm{NO}_{2} \\
\mathrm{CH}_{3}(\mathrm{HCOH}) \mathrm{CH}_{2} \mathrm{O}^{\bullet}+\mathrm{O}_{2} \rightarrow \mathrm{CH}_{3}(\mathrm{HCOH}) \mathrm{CHO}+\mathrm{HO}_{2}
\end{gathered}
$$

The net effect is to convert $\mathrm{NO}$ to $\mathrm{NO}_{2}$ and this produces more $\mathrm{O}_{3}$ as discussed above.

The reaction of alkenes with $\mathrm{O}_{3}$ forms many products including carbonyl compounds and $\mathrm{HO}^{\bullet}$ [4,37-39]. The reactions of alkenes with $\mathrm{O}_{3}$ are a small but dominant nighttime source of $\mathrm{HO}^{\bullet}$. For example, the $\mathrm{O}_{3}$ molecule inserts itself across the double bond of propene, Reaction 29.

$$
\mathrm{CH}_{3} \mathrm{CH}=\mathrm{CH}_{2}+\mathrm{O}_{3} \rightarrow \mathrm{CH}_{3} \mathrm{CH}^{\mathrm{OOO}} \mathrm{CH}_{2}
$$

The $\mathrm{CH}_{3} \mathrm{CH}_{2}{ }^{\mathrm{OOO}} \mathrm{CH}_{2}$ product fragments through two different reactions to make acetaldehyde, formaldehyde, $\mathrm{CH}_{2} \mathrm{O}$, and excited Criegee radicals, $\left[{ }^{\circ} \mathrm{CH}_{2} \mathrm{OO}^{\circ}\right]^{\neq}$and $\left[\mathrm{CH}_{3}{ }^{*} \mathrm{CHOO}{ }^{\circ}\right]^{\neq}$.

$$
\begin{aligned}
& \mathrm{CH}_{3} \mathrm{CH}^{\mathrm{OOO}} \mathrm{CH}_{2} \rightarrow \mathrm{CH}_{3} \mathrm{CHO}+\left[{ }^{\circ} \mathrm{CH}_{2} \mathrm{OO}^{\circ}\right]^{\neq} \\
& \mathrm{CH}_{3} \mathrm{CH}^{\stackrel{\mathrm{OOO}}{ } \mathrm{CH}_{2}} \rightarrow \mathrm{CH}_{2} \mathrm{O}+\left[\mathrm{CH}_{3}{ }^{\cdot} \mathrm{CHOO}\right]^{*}
\end{aligned}
$$

The excited Criegee radicals produce a wide variety of products, with one of the reactions producing $\mathrm{HO}^{\circ}$ radicals [37]. 


$$
\left[{ }^{\bullet} \mathrm{CH}_{2} \mathrm{OO}^{*}\right]^{\neq} \rightarrow \mathrm{HCO}^{\bullet}+\mathrm{HO}^{\bullet}
$$

The effect of reactive organic compounds on $\mathrm{O}_{3}$ formation is illustrated by three of simulations that initially contained $\mathrm{O}_{3}$, ethene and $\mathrm{NO}_{2}$. The $\mathrm{VOC} / \mathrm{NO}_{\mathrm{x}}$ ratios were 4,8 and $16 \mathrm{ppbC} / \mathrm{ppbN}$. The production of ozone for the chosen initial concentration of $\mathrm{NO}_{2}$ was $\mathrm{VOC}$ limited because the ozone mixing ratio increased with increasing initial concentrations of ethene, Figure 6.

Figure 6. Ozone mixing ratios are shown for the ethene cases.

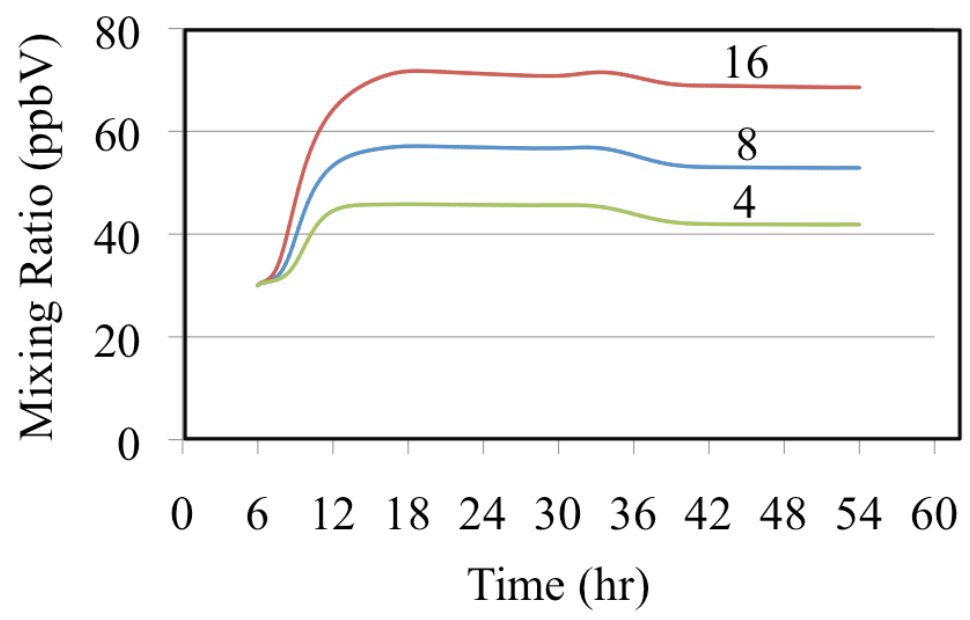

Figure 6 shows that for these cases $\mathrm{O}_{3}$ was formed rapidly on the first day but on the second day the air was aged and there was a small loss of $\mathrm{O}_{3}$. Notice that the rate of $\mathrm{O}_{3}$ formation during the morning of the first day depends on the $\mathrm{VOC} / \mathrm{NO}_{\mathrm{x}}$ ratio. The mixture with a $\mathrm{VOC} / \mathrm{NO}_{\mathrm{x}}$ ratio of $16 \mathrm{ppbC} / \mathrm{ppbN}$ forms $\mathrm{O}_{3}$ between 8:00 and 10:00 at a rate of $9.2 \mathrm{ppb} \mathrm{h}^{-1}$ while for $\mathrm{VOC} / \mathrm{NO}_{\mathrm{x}}$ ratios of 8 and $4 \mathrm{ppbC} / \mathrm{PPbN}$ the rates are 6.7 and $3.7 \mathrm{ppb} \mathrm{h}^{-1}$, respectively. The presence of ethene leads to the production of organic peroxy radicals $\left(\mathrm{CH}_{2} \mathrm{OH}-\mathrm{CH}_{2} \mathrm{O}_{2}{ }^{\circ}\right.$, in this case), Figure 7 and $\mathrm{HO}_{2}{ }^{\circ}$ radicals, Figure 8. Greater $\mathrm{VOC} / \mathrm{NO}_{\mathrm{x}}$ ratios lead to higher mixing ratios of peroxy radicals, $\mathrm{CH}_{2} \mathrm{OH}-\mathrm{CH}_{2} \mathrm{O}_{2}$ (in this case), and increased production of $\mathrm{O}_{3}$ due to more rapid conversion of $\mathrm{NO}$ to $\mathrm{NO}_{2}$.

Figure 7. The $\mathrm{CH}_{2} \mathrm{OH}-\mathrm{CH}_{2} \mathrm{O}_{2}{ }^{\cdot}$, radical mixing ratios are shown for the ethene cases. The number indicates the initial $\mathrm{VOC} / \mathrm{NO}_{\mathrm{x}}$ ratio in $\mathrm{ppbC} / \mathrm{ppbN}$.

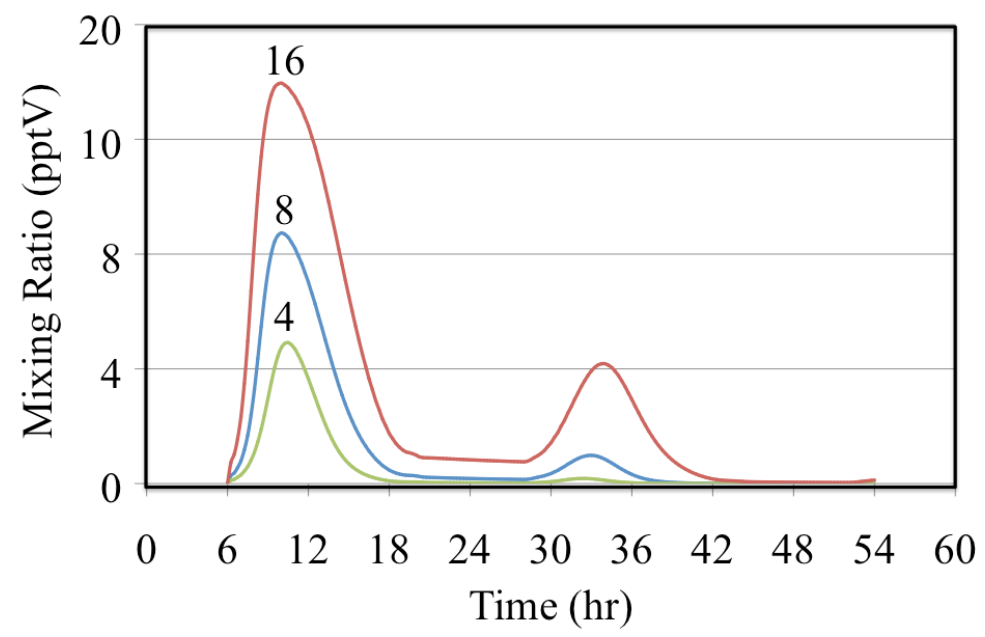


Figure 8. Hydroperoxy radical, $\mathrm{HO}_{2}{ }^{\circ}$, mixing ratios are shown for the ethene cases. The number indicates the initial $\mathrm{VOC} / \mathrm{NO}_{\mathrm{x}}$ ratio in $\mathrm{ppbC} / \mathrm{ppbN}$.

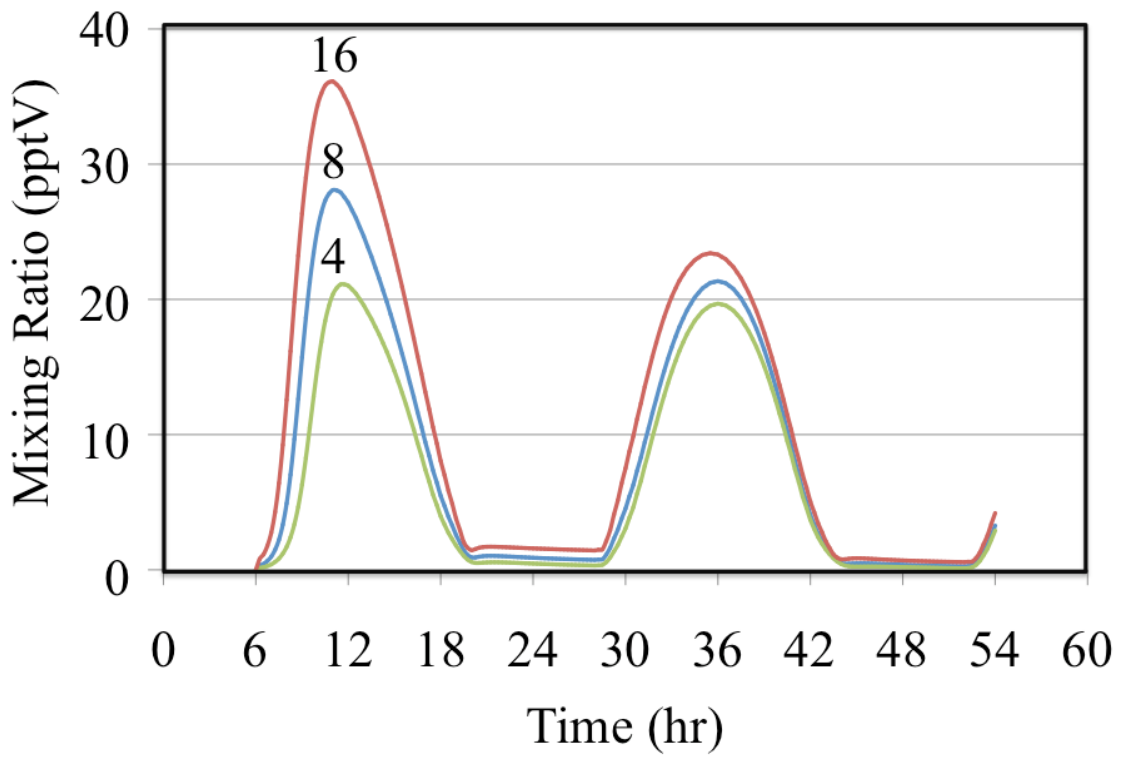

The formation of $\mathrm{O}_{3}$ occurs as a deviation from the PSSA, Equation 10. Equation 10 can be rearranged to give Equation 33.

$$
\frac{J_{\mathrm{NO}_{2}}}{k}=\frac{\left[\mathrm{O}_{3}\right][\mathrm{NO}]}{\left[\mathrm{NO}_{2}\right]}
$$

If a simulated atmosphere obeyed the PSSA, the left hand and right hand sides of Equation 33 would be equal. Since $J_{\mathrm{NO} 2} / k$, time dependent ratio of the photolysis frequency of $\mathrm{NO}_{2}$ to the rate constant for the $\mathrm{O}_{3}+\mathrm{NO}$ reaction, is fixed for a given set of conditions it can be used as a basis for comparison with the ratio, $\left[\mathrm{O}_{3}\right] \times[\mathrm{NO}] /\left[\mathrm{NO}_{2}\right]$. These are plotted on Figure 9 for the three simulated ethene cases.

Figure 9. The uppermost curve is the time dependent $\mathrm{NO}_{2}$ photolysis frequency divided by the rate constant for the $\mathrm{O}_{3}+\mathrm{NO}$ reaction. The lower plots are the ratio, $\left[\mathrm{O}_{3}\right] \times[\mathrm{NO}] /\left[\mathrm{NO}_{2}\right]$, for the three ethene cases. The number indicates the initial $\mathrm{VOC} / \mathrm{NO}_{\mathrm{x}}$ ratio in $\mathrm{ppbC} / \mathrm{ppbN}$.

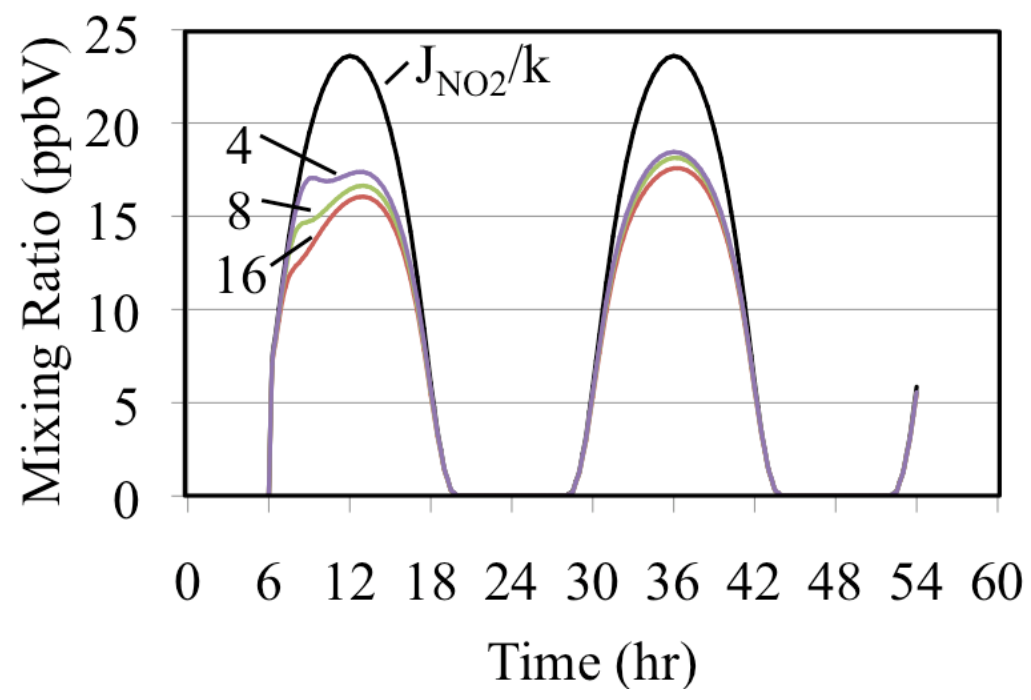


Figure 9 shows that the greater the initial mixing ratios of ethene the greater the deviation from the PSSA. Comparison of Figures 6 and 9 show that the greater the deviation from the PSSA the greater the formation. This result is in accord with the higher mixing ratios of peroxy radicals that are associated with higher $\mathrm{VOC} / \mathrm{NO}_{\mathrm{x}}$ ratios. Increased peroxy radical concentrations provide faster conversion of $\mathrm{NO}$ to $\mathrm{NO}_{2}$. This increases the production rate of $\mathrm{O}_{3}$ by the increasing the $\mathrm{NO}_{2}$ photolysis rate. The conversion of $\mathrm{NO}$ to $\mathrm{NO}_{2}$ reduces the $\mathrm{O}_{3}$ loss rate by reducing the rate of the $\mathrm{O}_{3}$ reaction with NO. Increasing the $\mathrm{O}_{3}$ production rate and decreasing its destruction rate at the same time has the net effect of increasing $\mathrm{O}_{3}$ mixing ratios. The greater the $\mathrm{O}_{3}$ production the greater the deviation from $\left[\mathrm{O}_{3}\right] \times[\mathrm{NO}] /\left[\mathrm{NO}_{2}\right]$ for these reasons [36].

$\mathrm{HO}_{2}{ }^{\circ}$ and $\mathrm{HO}^{\circ}$ radicals are in equilibrium and the partitioning between the concentrations of these two radicals depends on the NO concentration. In this case higher mixing ratios of $\mathrm{HO}_{2}{ }^{\circ}$ are associated with lower mixing ratios of $\mathrm{HO}^{\circ}$, Figures 8 and 10.

Figure 10. Hydroxyl radical, $\mathrm{HO}^{\circ}$, mixing ratios are shown for the ethene cases. The number indicates the initial $\mathrm{VOC} / \mathrm{NO}_{\mathrm{x}}$ ratio in $\mathrm{ppbC} / \mathrm{ppbN}$.

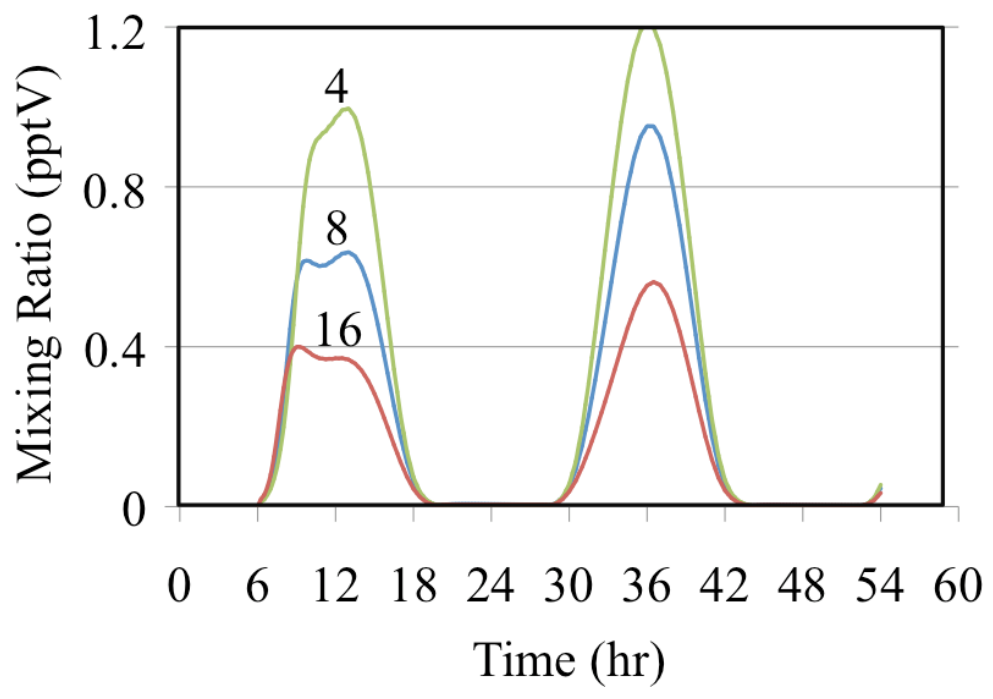

Aromatic compounds are the third type of hydrocarbon that is important for air pollution, and is the subject of ongoing research. The oxidation mechanism of aromatic compounds leads to the production of peroxy radicals and high molecular weight compounds that may condense to produce secondary organic aerosols. The chemistry of oxidation of aromatic compounds is very complicated and there are too many compounds and reactions to include in a mechanism to be routinely used for air quality modeling. There are at least several hundred reactions and products for a parent aromatic compound [40]. The chemistry of a reaction of the $\mathrm{HO}^{\circ}$ radical with an organic substituent attached to an aromatic ring is the easiest to describe. However, only about $10 \%$ of the hydroxy radicals abstract hydrogen atoms from an alkyl group, attached to an aromatic ring. In this case the chemical mechanism will be that of the substituent group. For example, when $\mathrm{HO}^{\circ}$ reacts with the methyl group of toluene, the subsequent chemistry is similar to alkanes. A hydrogen atom is abstracted and an oxygen molecule adds to the $\mathrm{CH}_{2}{ }^{\circ}$ radical on the aromatic ring to make peroxy radical. The peroxy radical may react with NO to produce benzaldehyde. 
The addition of $\mathrm{HO}^{\circ}$ to an aromatic ring is the dominant aromatic reaction [40]. The subsequent reactions that follow this addition reaction may lead to either the breaking of the aromatic ring or ring-retaining products. In the case of the simplest aromatic compound, benzene, phenol is a ring-retaining product that is produced in high yield. Bloss et al. [41] supports a phenol yield of 0.52 while Berndt and Böge [42] determined the yield of phenol to be $0.61 \pm 0.07$ in the presence and absence of $\mathrm{NO}_{\mathrm{x}}$.

A very large number of highly reactive compounds result when the ring breaks. The reactive compounds include a large number of dicarbonyl compounds that contain two carbonyl groups $(\mathrm{C}=\mathrm{O})$, are produced. These dicarbonyl compounds have a complicated and relatively unknown chemistry. Studies regarding the ring-opening products of the $\mathrm{HO}^{\circ}$-benzene reaction are sparse. The main aspects of their formation are uncertain due to lack of good experimental techniques for their quantification, a lack of commercially available standards, and their high reactivity.

For example, Gomez Alvarez et al. [43] confirmed the existence of dicarbonyl production and they found that the yields of dicarbonyls could be high. Fast ring-cleavage was observed, due to a peak in observed $\gamma$-dicarbonyls shortly after the chamber was opened to sunlight. Also, high yields of dicarbonyls (e.g., glyoxal) imply a high formation rate of $\mathrm{HO}^{\bullet}$ into the system. They found that yields of glyoxal with values of $42 \pm 3 \%$ and $36 \pm 2 \%$ in two successive experiments. To be able to investigate the existence of higher molecular weight dicarbonyl compounds they had to synthesize cis- and trans-butenedial for calibration purposes. For one experiment they found total butenedial yields of $17 \pm 9 \%$ with a breakdown of $8 \pm 4 \%$ cis-butenedial and $9 \pm 5 \%$ trans-butenedial. For a second experiment they found total butenedial yields of $15 \pm 6 \%$; the breakdown was $7 \pm 3 \%$ and $7 \pm 3 \%$ for the cis and trans isomers, respectively.

\subsection{The Atmospheric Chemistry of Aldehydes, Ketones and Peroxyacetyl Nitrate}

Aldehydes and ketones contain a carbonyl group, $\mathrm{C}=\mathrm{O}$. As presented above, aldehydes and ketones are oxidation products of VOC and many have biogenic and anthropogenic emission sources [9,35]. Formaldehyde is the simplest aldehyde. Higher molecular weight aldehydes follow the template $\mathrm{RCHO}$; they have one hydrogen atom attached to the carbonyl and another organic functional group attached to it. Acetone, $\mathrm{CH}_{3}(\mathrm{CO}) \mathrm{CH}_{3}$ is the simplest ketone. Higher molecular weight ketones follow the template $\mathrm{R}_{1}(\mathrm{CO}) \mathrm{R}_{2}$; they have two organic functional groups attached to the carbonyl and these groups maybe the same or different.

Aldehydes and ketones react with $\mathrm{HO}^{\circ}$ by abstraction of a hydrogen atom. The overall scheme has some similarity to the alkane oxidation scheme with some exceptions. Reaction 34 shows formaldehyde as an example of one exception.

$$
\mathrm{CH}_{2} \mathrm{O}+\mathrm{HO}^{\bullet} \rightarrow \mathrm{CHO}^{\bullet}+\mathrm{H}_{2} \mathrm{O}
$$

The carbonyl radical, $\mathrm{CHO}^{\circ}$, does not add to oxygen to produce a peroxy radical but rather, it reacts with oxygen to produce the $\mathrm{HO}_{2}{ }^{\circ}$ radical.

$$
\mathrm{CHO}^{\bullet}+\mathrm{O}_{2} \rightarrow \mathrm{CO}+\mathrm{HO}_{2}^{\cdot}
$$

The carbonyl group is a strong chromophore for ultraviolet radiation. The absorption of ultraviolet radiation causes photo-dissociation of these compounds and some of the reaction channels lead to the 
production of radicals. For example, formaldehyde has two photolysis reactions that occur in the lower troposphere. Reaction 36 yields molecular products while Reaction 37 yields radical products.

$$
\begin{gathered}
\mathrm{CH}_{2} \mathrm{O}+\mathrm{h} v \rightarrow \mathrm{H}_{2}+\mathrm{CO} \\
\mathrm{CH}_{2} \mathrm{O}+\mathrm{h} v \rightarrow \mathrm{H}^{\bullet}+\mathrm{CHO}^{\circ}
\end{gathered}
$$

The net effect of Reaction 37 is to produce two $\mathrm{HO}_{2}{ }^{\circ}$ radicals because the $\mathrm{CHO}^{\bullet}$ reacts according to Reaction 35 and the hydrogen atom reacts with oxygen to produce another $\mathrm{HO}_{2}{ }^{\circ}$.

$$
\mathrm{H}^{\bullet}+\mathrm{O}_{2} \rightarrow \mathrm{HO}_{2}^{\bullet}
$$

Under highly polluted urban conditions the photolysis of formaldehyde can be a source of $\mathrm{HO}_{\mathrm{x}}$ radicals that is as important as $\mathrm{O}_{3}$.

Acetaldehyde, $\mathrm{CH}_{3} \mathrm{CHO}$, is the next higher molecular weight aldehyde. It reacts in the polluted atmosphere to produce peroxyacetyl nitrate, $\mathrm{CH}_{3}(\mathrm{CO}) \mathrm{O}_{2} \mathrm{NO}_{2}$, (PAN) [3]. PAN is an important compound because it serves as a reservoir of acetyl radicals and $\mathrm{NO}_{2}$ and it is a strong lachrymator. The mechanism of PAN formation begins with $\mathrm{HO}^{\circ}$ abstracting the hydrogen atom that is attached to the carbonyl group in acetaldehyde. The addition of oxygen to the resulting $\mathrm{CH}_{3} \mathrm{CO}$ radical produces the acetyl peroxy radical.

$$
\begin{gathered}
\mathrm{CH}_{3} \mathrm{CHO}+\mathrm{HO}^{\circ} \rightarrow \mathrm{CH}_{3} \mathrm{CO}^{\circ}+\mathrm{H}_{2} \mathrm{O} \\
\mathrm{CH}_{3} \mathrm{CO}^{\circ}+\mathrm{O}_{2} \rightarrow \mathrm{CH}_{3}(\mathrm{CO}) \mathrm{O}_{2} \cdot \\
\mathrm{CH}_{3}(\mathrm{CO}) \mathrm{O}_{2}+\mathrm{NO}_{2} \rightarrow \mathrm{CH}_{3}(\mathrm{CO}) \mathrm{O}_{2} \mathrm{NO}_{2}
\end{gathered}
$$

PAN decomposes thermally to reproduce acetyl peroxy radicals and $\mathrm{NO}_{2}$.

$$
\mathrm{CH}_{3}(\mathrm{CO}) \mathrm{O}_{2} \mathrm{NO}_{2} \rightarrow \mathrm{CH}_{3}(\mathrm{CO}) \mathrm{O}_{2}+\mathrm{NO}_{2}
$$

PAN is in equilibrium with $\mathrm{NO}_{2}$ and the $\mathrm{CH}_{3}(\mathrm{CO}) \mathrm{O}_{2}$ radical at temperatures near $25{ }^{\circ} \mathrm{C}$. PAN is much more stable at lower temperatures and the lifetime of PAN becomes longer. PAN can be transported over long distances in the upper troposphere where the temperatures are colder and its photolysis becomes important. The photolysis of PAN proceeds by two pathways. The faster pathway forms the acetyl peroxy radical and $\mathrm{NO}_{2}$. The slower photolysis route involves the destruction of PAN by the formation of the methyl peroxy radical, $\mathrm{CO}_{2}$ and $\mathrm{NO}_{3}$. Higher molecular weight aldehydes form acyl peroxy radicals that may react to produce higher homologs of PAN $[3,44]$.

\subsection{The Nighttime Chemistry of the Nitrate Radical}

The nitrate radical, $\mathrm{NO}_{3}{ }^{\circ}$, is the nighttime analog of the hydroxyl radical and it is produced by the reaction of $\mathrm{O}_{3}$ with $\mathrm{NO}_{2}$.

$$
\mathrm{O}_{3}+\mathrm{NO}_{2} \rightarrow \mathrm{O}_{2}+\mathrm{NO}_{3}^{\cdot}
$$

Daytime concentrations of $\mathrm{NO}_{3}{ }^{\circ}$ are low due to its rapid photolysis reactions with photolysis frequencies that are several times greater than $\mathrm{NO}_{2}$. There are two photolysis reactions.

$$
\begin{gathered}
\mathrm{NO}_{3} \cdot \mathrm{h} v \rightarrow \mathrm{O}_{2}+\mathrm{NO} \\
\mathrm{NO}_{3}+\mathrm{h} v \rightarrow \mathrm{O}\left({ }^{3} \mathrm{P}\right)+\mathrm{NO}_{2}
\end{gathered}
$$


The $\mathrm{NO}_{3}{ }^{\circ}$ radical becomes much more important at night when its concentration increases, Figure 11.

Figure 11. Nitrate radical mixing ratios for the ethene cases. The number indicates the initial $\mathrm{VOC} / \mathrm{NO}_{\mathrm{x}}$ ratio in $\mathrm{ppbC} / \mathrm{ppbN}$.

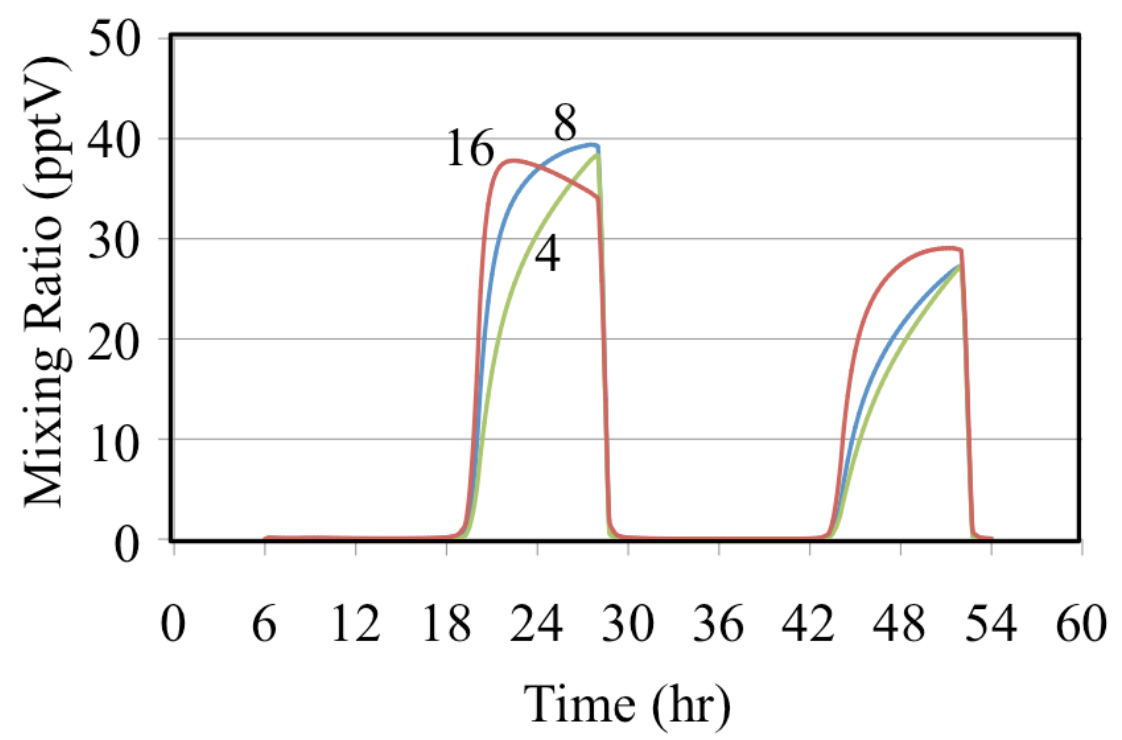

The $\mathrm{NO}_{3}{ }^{\circ}$ reacts with $\mathrm{NO}_{2}$ to produce dinitrogen pentoxide, $\mathrm{N}_{2} \mathrm{O}_{5}$, but this is not a stable compound and it is in equilibrium with $\mathrm{NO}_{3}{ }^{\circ}$ and $\mathrm{NO}_{2}$.

$$
\begin{aligned}
& \mathrm{NO}_{3}{ }^{\cdot}+\mathrm{NO}_{2} \rightarrow \mathrm{N}_{2} \mathrm{O}_{5} \\
& \mathrm{~N}_{2} \mathrm{O}_{5} \rightarrow \mathrm{NO}_{3} \cdot+\mathrm{NO}_{2}
\end{aligned}
$$

What makes $\mathrm{N}_{2} \mathrm{O}_{5}$ significant is that it can react with water on aerosol and other surfaces to produce nitric acid, $\mathrm{HNO}_{3}$. This nighttime loss of reactive nitrogen may reduce the formation of $\mathrm{O}_{3}$ on subsequent days during the summer season.

The $\mathrm{NO}_{3}{ }^{\cdot}$ radical reacts with many organic compounds [45]. Alkanes and aromatic compounds react slowly with $\mathrm{NO}_{3}{ }^{\circ}$ but the radical reacts rapidly with alkenes by addition. Possibly the most important organic reaction is the reaction of $\mathrm{NO}_{3}{ }^{\circ}$ with aldehydes because it is a strong source of nighttime peroxy radicals [46,47]. For example, formaldehyde and $\mathrm{NO}_{3}{ }^{\circ}$ react to produce $\mathrm{HNO}_{3}$ and $\mathrm{CHO}^{\circ}$ radicals. The reaction proceeds through the abstraction of a hydrogen attached to the carbonyl group.

$$
\mathrm{NO}_{3}{ }^{\circ}+\mathrm{CH}_{2} \mathrm{O} \rightarrow \mathrm{HNO}_{3}+\mathrm{CHO}^{\bullet}
$$

The $\mathrm{CHO}^{\circ}$ radical reacts immediately with molecular oxygen to produce $\mathrm{HO}_{2}{ }^{\bullet}$ radicals as discussed above, Reaction 35. The reaction of $\mathrm{NO}_{3}{ }^{\circ}$ with acetaldehyde can lead to the formation of PAN. The hydrogen attached to the carbonyl group is abstracted and then Reaction 49 is followed by Reactions 40 and 41 to produce PAN [47].

$$
\mathrm{NO}_{3}{ }^{\circ}+\mathrm{CH}_{3} \mathrm{CHO} \rightarrow \mathrm{HNO}_{3}+\mathrm{CH}_{3} \mathrm{CO}^{\bullet}
$$

The reaction of $\mathrm{NO}_{3}{ }^{\circ}$ with alkenes is similar to $\mathrm{HO}^{\circ}$; it reacts by addition but this process is more prevalent during the nighttime due to the typical higher concentrations of $\mathrm{NO}_{3}{ }^{\circ}$. The $\mathrm{NO}_{3}{ }^{\circ}$ participates in radical termination reactions too and these are discussed below. 


\subsection{Radical Termination, the Production of Atmospheric Acids and Hydrogen Peroxides}

Tropospheric chemistry involves many chain reactions as discussed above. At some point the chain reactions must terminate. The reaction of $\mathrm{HO}^{\circ}$ with $\mathrm{NO}_{2}$ to the form $\mathrm{HNO}_{3}$, Reaction 50, and the self-reaction of $\mathrm{HO}_{2}{ }^{\circ}$ to form hydrogen peroxide, Reaction 51 are among the most important.

$$
\begin{gathered}
\mathrm{HO}^{\bullet}+\mathrm{NO}_{2} \rightarrow \mathrm{HNO}_{3} \\
\mathrm{HO}_{2}+\mathrm{HO}_{2}^{\cdot}\left(+\mathrm{H}_{2} \mathrm{O}, \mathrm{M}\right) \rightarrow \mathrm{H}_{2} \mathrm{O}_{2}+\mathrm{O}_{2}
\end{gathered}
$$

Note that the overall rate parameter for the self-reaction of $\mathrm{HO}_{2}{ }^{\circ}$ depends on atmospheric pressure and the water vapor concentration [48]. Figure 12 shows the formation of $\mathrm{HNO}_{3}$ for the ethene cases where NO is relatively high.

Figure 12. Nitric acid mixing ratios are shown for the ethene cases. The number indicates the initial $\mathrm{VOC} / \mathrm{NO}_{\mathrm{x}}$ ratio in $\mathrm{ppbC} / \mathrm{ppbN}$.

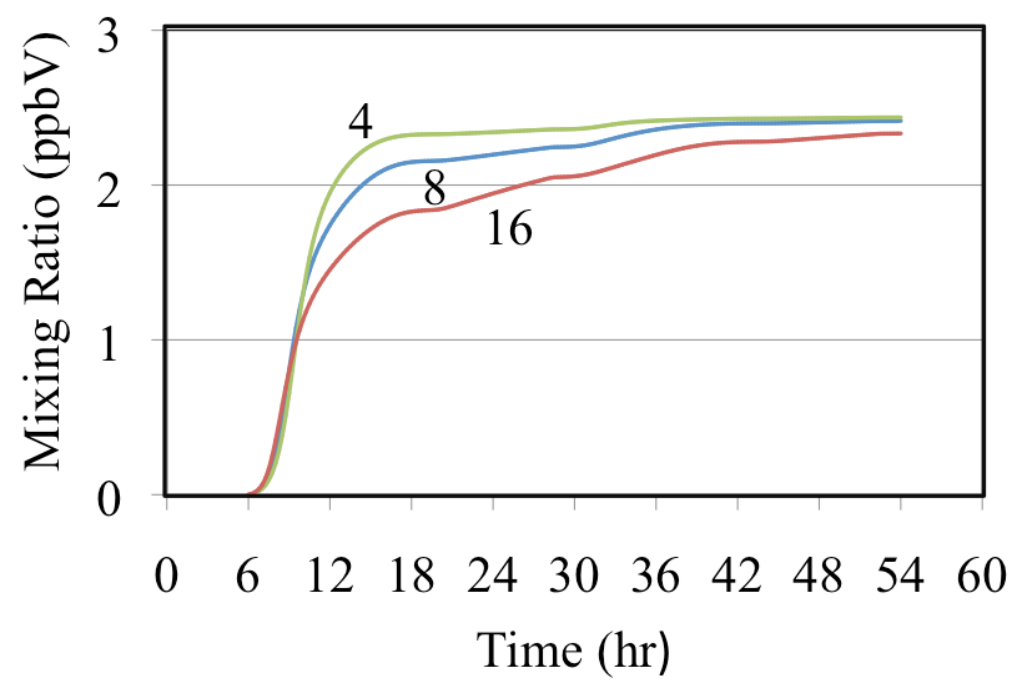

Figure 12 shows that the mixing ratios of $\mathrm{HNO}_{3}$ decrease as the $\mathrm{VOC} / \mathrm{NO}_{\mathrm{x}}$ ratio increases for the ethene simulations. This is consistent with the decrease in the mixing ratio of $\mathrm{HO}^{\circ}$ shown in Figure 10. The reaction of $\mathrm{HO}^{\circ}$ with $\mathrm{NO}_{2}$ is more important for urban conditions where $\mathrm{NO}$ concentrations are high while the self-reaction of $\mathrm{HO}_{2}{ }^{-}$is more important for rural and remote conditions where NO concentrations are low. Figure 13 shows hydrogen peroxide formation for the ethene cases.

Figure 13 shows a typical trend with the mixing ratio of $\mathrm{H}_{2} \mathrm{O}_{2}$ depending on the VOC to $\mathrm{NO}_{\mathrm{x}}$ ratio. Higher VOC concentrations relative to the NO concentration lead to the production of greater concentrations of $\mathrm{HO}_{2}{ }^{\circ}$. Higher concentrations of $\mathrm{HO}_{2}{ }^{\circ}$ result in greater amounts of termination through the $\mathrm{HO}_{2}{ }^{\circ}$ self reaction, Reaction 51, producing more $\mathrm{H}_{2} \mathrm{O}_{2}$.

Some termination of the radical chains occurs through the reactions of $\mathrm{HO}_{2}{ }^{*}$ with other peroxy radicals at low NO concentrations. These reactions typically lead to the production of organic hydrogen peroxides. For example the methylperoxy radical reacts with the $\mathrm{HO}_{2}{ }^{\bullet}$ radical to produce methyl hydrogen peroxide, $\mathrm{CH}_{3} \mathrm{OOH}$.

$$
\mathrm{CH}_{3} \mathrm{O}_{2}{ }^{\cdot}+\mathrm{HO}_{2}^{\cdot} \rightarrow \mathrm{CH}_{3} \mathrm{OOH}+\mathrm{O}_{2}
$$


Figure 13. Hydrogen peroxide mixing ratios are shown for the ethene cases. The number indicates the initial $\mathrm{VOC} / \mathrm{NO}_{\mathrm{x}}$ ratio in $\mathrm{ppbC} / \mathrm{ppbN}$.

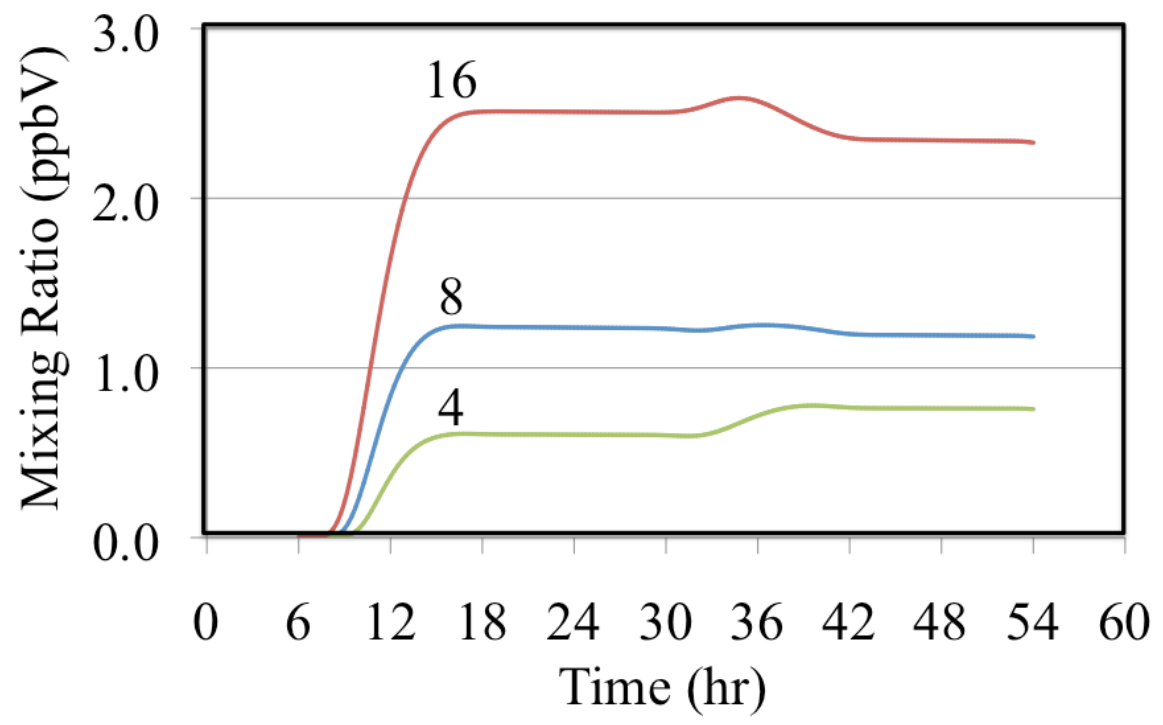

The reactions of organic peroxy radicals are more complicated. For many organic peroxy radicals there are two reactions that occur. The first is the disproportion reaction that yields oxygen and alkoxy radicals.

$$
\mathrm{CH}_{3} \mathrm{O}_{2}{ }^{\circ}+\mathrm{CH}_{3} \mathrm{O}_{2}^{\cdot} \rightarrow 2 \mathrm{CH}_{3} \mathrm{O}^{\cdot}+\mathrm{O}_{2}
$$

The second type of organic peroxy radicals-radical reaction is the transfer of a hydrogen atom from a carbon atom that is adjacent to the peroxy oxygen atoms. The hydrogen atom is transferred to the oxygen atom that is adjacent to the other carbonyl group. For example, in the case of the self-reaction of the methylperoxy radical, formaldehyde and methanol are produced.

$$
\mathrm{CH}_{3} \mathrm{O}_{2}^{\cdot}+\mathrm{CH}_{3} \mathrm{O}_{2}^{\cdot} \rightarrow \mathrm{CH}_{3} \mathrm{OH}+\mathrm{CH}_{2} \mathrm{O}+\mathrm{O}_{2}
$$

In the case of two different organic peroxy radicals there is the disproportion reaction and the transfer of the hydrogen atom that can go in both directions.

$$
\begin{aligned}
& \mathrm{CH}_{3} \mathrm{O}_{2}{ }^{-}+\mathrm{CH}_{3} \mathrm{CH}_{2} \mathrm{O}_{2}{ }^{\cdot} \rightarrow \mathrm{CH}_{3} \mathrm{O}+\mathrm{CH}_{3} \mathrm{CH}_{2} \mathrm{O}+\mathrm{O}_{2} \\
& \mathrm{CH}_{3} \mathrm{O}_{2}{ }^{-}+\mathrm{CH}_{3} \mathrm{CH}_{2} \mathrm{O}_{2}{ }^{\cdot} \rightarrow \mathrm{CH}_{3} \mathrm{OH}+\mathrm{CH}_{3} \mathrm{CHO}+\mathrm{O}_{2} \\
& \mathrm{CH}_{3} \mathrm{O}_{2}{ }^{-}+\mathrm{CH}_{3} \mathrm{CH}_{2} \mathrm{O}_{2}{ }^{\cdot} \rightarrow \mathrm{CH}_{2} \mathrm{O}+\mathrm{CH}_{3} \mathrm{CH}_{2} \mathrm{OH}+\mathrm{O}_{2}
\end{aligned}
$$

The transfer of a hydrogen atom can only go in one direction in the case of acyl organic peroxy radicals. For acyl organic peroxy radicals there is no adjacent hydrogen atom on the carbon atom adjacent to the peroxy oxygen atoms [49]. For example the reaction of the methylperoxy radical with the acetyl peroxy radical there are two major reactions.

$$
\begin{aligned}
& \mathrm{CH}_{3} \mathrm{O}_{2}{ }^{-}+\mathrm{CH}_{3} \mathrm{CO}_{3}{ }^{-} \rightarrow \mathrm{CH}_{3} \mathrm{O}^{\circ}+\mathrm{CH}_{3} \mathrm{CO}_{2}{ }^{-}+\mathrm{O}_{2} \\
& \mathrm{CH}_{3} \mathrm{O}_{2}{ }^{-}+\mathrm{CH}_{3} \mathrm{CO}_{3}{ }^{-} \rightarrow \mathrm{CH}_{2} \mathrm{O}+\mathrm{CH}_{3} \mathrm{COOH}+\mathrm{O}_{2}
\end{aligned}
$$

The $\mathrm{CH}_{3} \mathrm{CO}_{2}{ }^{\circ}$ reacts with molecular oxygen to produce carbon dioxide and the methyl peroxy radical. 


$$
\mathrm{CH}_{3} \mathrm{CO}_{2}^{\cdot}+\mathrm{O}_{2} \rightarrow \mathrm{CH}_{3} \mathrm{O}_{2}+\mathrm{CO}_{2}
$$

Figure 14 shows the formation of organic peroxides from the reaction of methyl peroxy radical with organic peroxy radicals to form peroxides of the form $\mathrm{CH}_{3} \mathrm{OOR}$.

Figure 14. Organic peroxide mixing ratios are shown for the ethene cases. The number indicates the initial $\mathrm{VOC} / \mathrm{NO}_{\mathrm{x}}$ ratio in $\mathrm{ppbC} / \mathrm{ppbN}$.

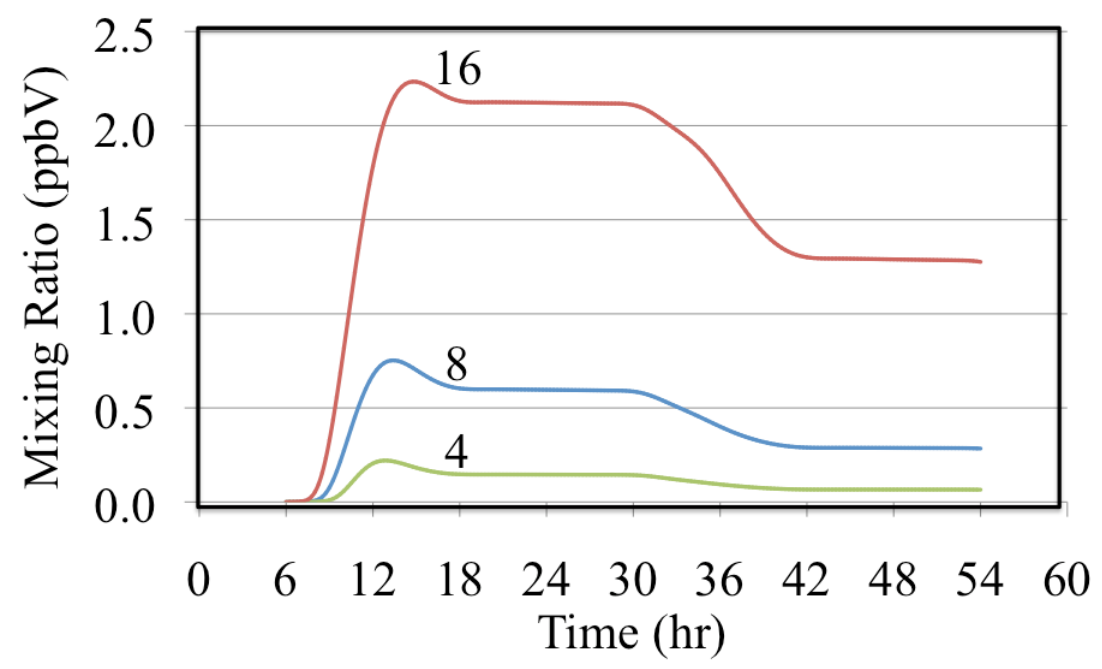

The reactions of organic peroxy radicals with $\mathrm{NO}_{3}$ radical may be highly important but there is relatively little data available as they are difficult to study in the laboratory. Organic peroxy radicals are expected to react with $\mathrm{NO}_{3}{ }^{\circ}$ as shown in Reaction 61 [50].

$$
\mathrm{RO}_{2}{ }^{\cdot}+\mathrm{NO}_{3} \rightarrow \mathrm{RO}^{\bullet}+\mathrm{NO}_{2}+\mathrm{O}_{2}
$$

But the reaction is not chain terminating because the $\mathrm{RO}$ will react to produce additional radicals.

Another reaction that is not chain terminating is the reaction of $\mathrm{HO}^{\circ}$ with $\mathrm{SO}_{2}$, in contrast to its reaction with $\mathrm{NO}_{2}$. The reaction of $\mathrm{HO}^{\circ}$ with $\mathrm{SO}_{2}$ is an important source of sulfate and acid deposition but it does not greatly affect the atmospheric $\mathrm{HO}_{\mathrm{x}}$ concentration. The reaction follows the following mechanism [51].

$$
\begin{gathered}
\mathrm{HO}^{\bullet}+\mathrm{SO}_{2} \rightarrow \mathrm{HOSO}_{2}{ }^{\bullet}+\mathrm{O}_{2} \\
\mathrm{HOSO}_{2}+\mathrm{O}_{2} \rightarrow \mathrm{SO}_{3}^{\bullet}+\mathrm{HO}_{2} \\
\mathrm{SO}_{3}^{\cdot}+\mathrm{H}_{2} \mathrm{O} \rightarrow \mathrm{H}_{2} \mathrm{SO}_{4}
\end{gathered}
$$

\subsection{The Behavior of a Complex Atmospheric Chemistry System}

The purpose of this section is to illustrate the chemistry discussed above and to show how it applies to a more complex mixture that is closer to the real polluted atmosphere. There are important interactions between atmospheric inorganic chemistry and organic chemistry that affect the production of $\mathrm{O}_{3}$, peroxy radicals, $\mathrm{HNO}_{3}$ organic peroxides and many other species. These interactions are examined through the simulation of the complex mixture described in Tables 2 and 3 . The simulated 
case is a relatively realistic mixture of air pollutants with their emissions based on measurements made at Howard University's atmospheric field site near Beltsville, Maryland.

Figure 15 shows the production of $\mathrm{O}_{3}$ from $\mathrm{NO}$ and $\mathrm{NO}_{2}$. The mixing ratios of $\mathrm{NO}$ and $\mathrm{O}_{3}$ were initialized to high values for this box model simulation. Under polluted urban conditions NO may accumulate near the surface during the nighttime and during the early morning rush hours. The onset of convection mixes $\mathrm{O}_{3}$ from aloft to rapidly titrate the $\mathrm{NO}$ to produce $\mathrm{NO}_{2}$. The photolysis of $\mathrm{NO}_{2}$ produces $\mathrm{O}_{3}$. This increase in $\mathrm{O}_{3}$ drives down the $\mathrm{NO}$ mixing ratio further during the first few hours of the simulation. Emissions maintain a $\mathrm{NO}_{2}$ mixing ratio of a few parts per billion for the entire episode. The mixing ratios of $\mathrm{O}_{3}$ and $\mathrm{NO}_{2}$ decrease during the nighttime due to the reaction of $\mathrm{NO}_{2}$ with $\mathrm{O}_{3}$ to produce $\mathrm{NO}_{3}$ radical and $\mathrm{N}_{2} \mathrm{O}_{5}$. Nighttime chemistry converts $\mathrm{NO}_{\mathrm{x}}$ to $\mathrm{HNO}_{3}$, thereby removing reactive nitrogen from the atmosphere.

Figure 15. Ozone, $\mathrm{NO}$ and $\mathrm{NO}_{2}$ mixing ratios are shown for the polluted urban atmosphere case.

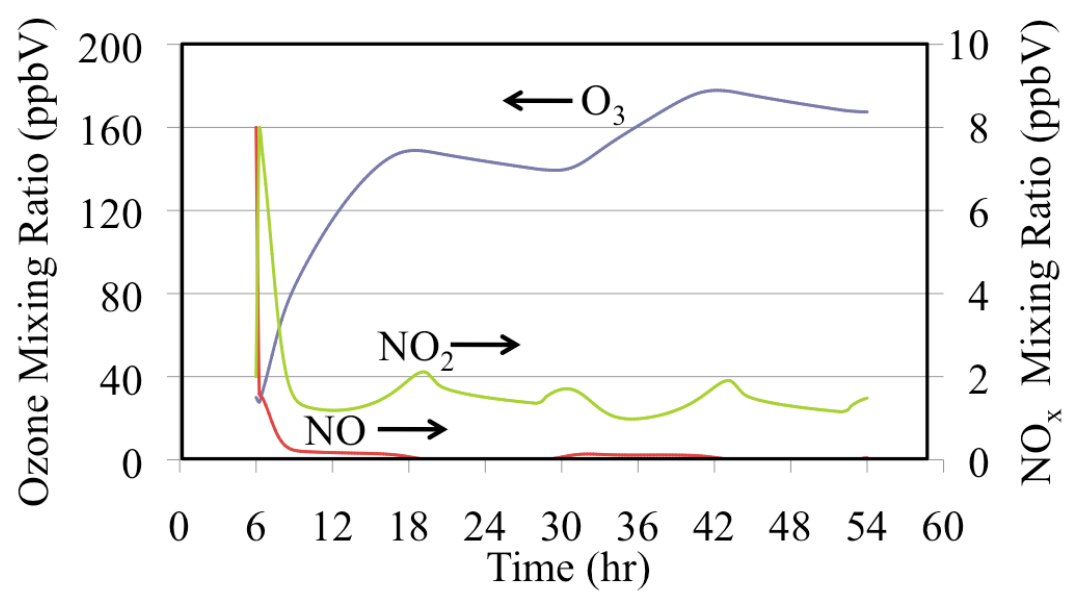

Figure 16. Hydroxyl radical, nitrate radical and dinitrogen pentoxide mixing ratios are shown for the polluted urban atmosphere case.

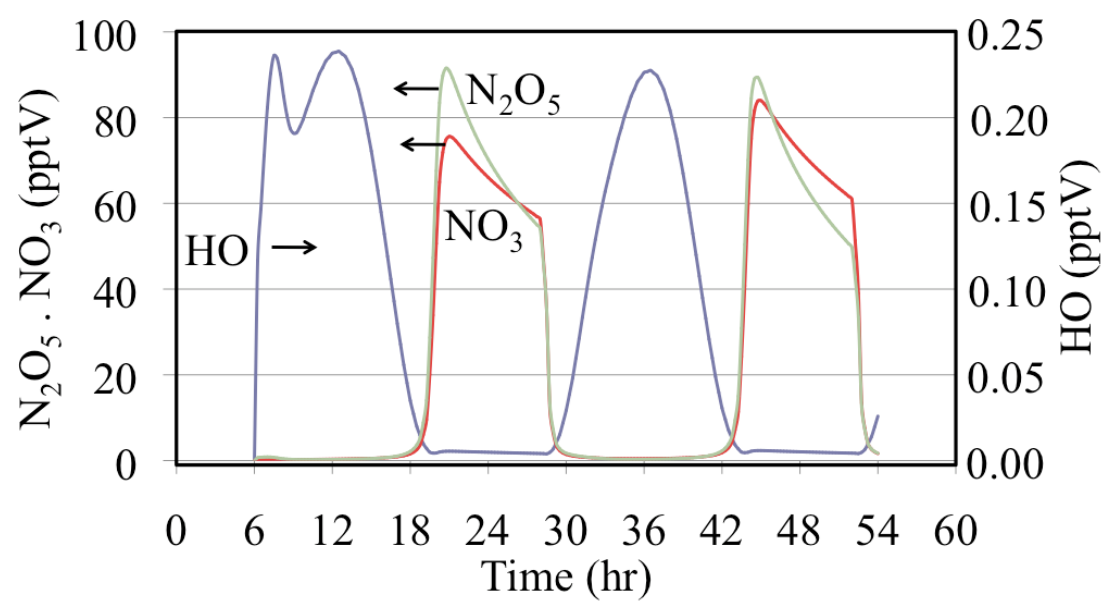

Figure 16 shows that after sunset the mixing ratios of $\mathrm{N}_{2} \mathrm{O}_{5}$ and $\mathrm{NO}_{3}$ increase rapidly. Later during the night the $\mathrm{NO}_{3}$ mixing ratios decrease due to the loss of $\mathrm{NO}_{3}$ through titration by $\mathrm{NO}$ emissions and, to a lesser extent, through the reactions of $\mathrm{NO}_{3}$ with aldehydes and alkenes. In addition $\mathrm{N}_{2} \mathrm{O}_{5}$ reacts with liquid water on aerosol and other surfaces although not included in this gas-phase simulation. 
The time dependent profiles for the $\mathrm{HO}^{\circ}$ are more complicated than those in Figure 10 . The $\mathrm{HO}^{\circ}$ mixing ratios are much lower during the nighttime but they do not fall to zero due to their production from the reaction of $\mathrm{O}_{3}$ with alkenes. Another feature is that on the first day there is a double peak due to changes between the major sources and sinks of $\mathrm{HO}^{\circ}$. One change in the $\mathrm{HO}^{\circ}$ sink is due to a severe drop in the initial mixing ratios of biogenically emitted alkenes.

The major daytime sources of $\mathrm{HO}^{\circ}$ are the photolysis of formaldehyde and $\mathrm{O}_{3}$, Figures 17 and 18 . Figure 17 shows the production rates and Figure 18 shows the relative production rates. In these figures the formaldehyde $\mathrm{HO}^{\circ}$ production rate was calculated by multiplying production rate of $\mathrm{HO}_{2}{ }^{\circ}$ from formaldehyde photolysis by the fraction of $\mathrm{HO}_{2}{ }^{\circ}$ radicals that react with NO.

Figure 17. Production rates of $\mathrm{HO}^{\bullet}$ initiated through the photolysis of formaldehyde (red line) and the photolysis of $\mathrm{O}_{3}$ (blue line) are shown for the polluted urban atmosphere case.

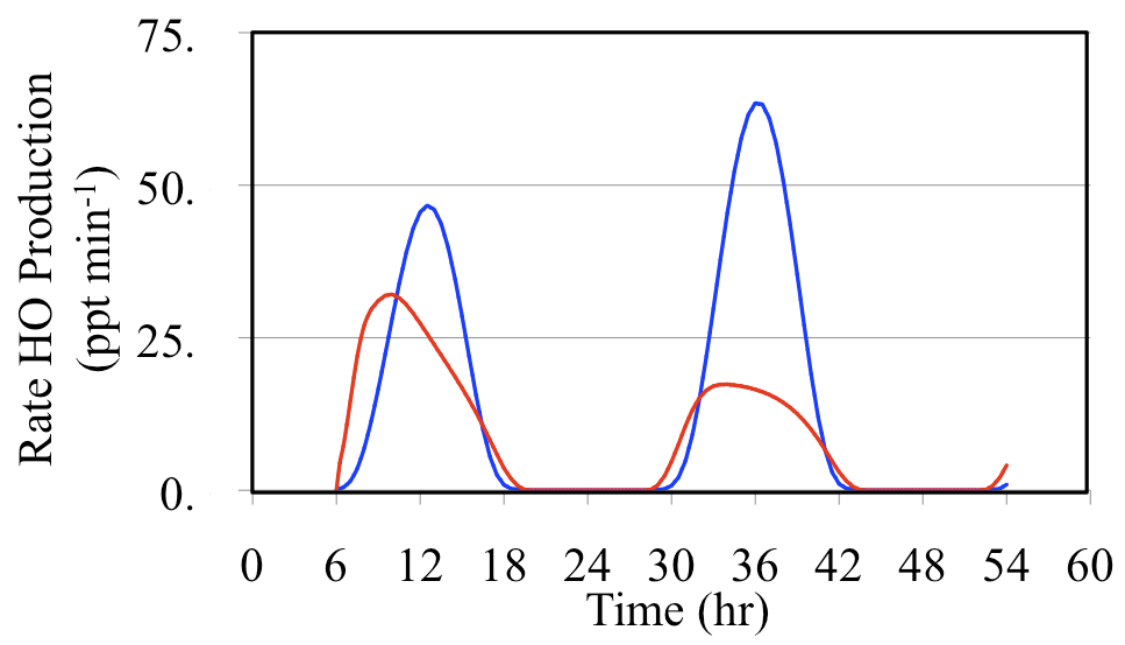

Figure 18. Daytime relative production rates of $\mathrm{HO}^{\bullet}$ resulting from the photolysis of formaldehyde (red line) and the photolysis of $\mathrm{O}_{3}$ (blue line) are shown for the polluted urban atmosphere case.

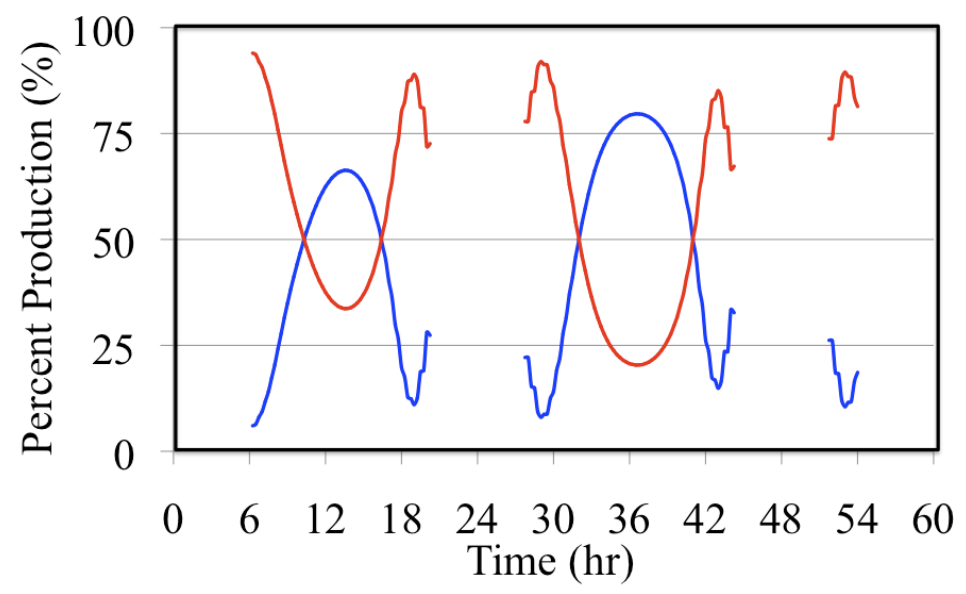

Formaldehyde photolysis is the more important source during the early morning and late afternoon hours. The time dependent profile of the formaldehyde photolysis source is skewed toward the morning hours while the time dependent profile of the $\mathrm{O}_{3}$ photolysis source mirrors the $\mathrm{O}_{3}$ photolysis 
rate constant. However, when these two $\mathrm{HO}^{\bullet}$ sources are examined on a percentage basis the profiles appear to be much more symmetrical, Figure 18.

Reaction of $\mathrm{HO}^{\circ}$ is almost equally divided between inorganic and organic species, Table 4. A very large fraction of $\mathrm{HO}^{\circ}$ reacts with $\mathrm{CO}$. For $\mathrm{VOC}$, the reaction of $\mathrm{HO}^{\circ}$ with aldehydes and other products of hydrocarbon oxidation were the second most important class of hydroxyl radical reactions while the reaction of $\mathrm{HO}^{\circ}$ with the hydrocarbons was the third.

Table 4. Relative percentages of $\mathrm{HO}^{\bullet}$ radicals reacting with chemical species over the entire simulated period.

\begin{tabular}{lr}
\hline \multicolumn{1}{c}{ Species } & Percent (\%) \\
\hline Inorganic & \\
$\mathrm{CO}$ & 35.12 \\
$\mathrm{SO}_{2}$ & 4.33 \\
$\mathrm{NO}_{\mathrm{x}}$ & 3.05 \\
$\mathrm{H}_{2} \mathrm{O}_{2}$ & 2.17 \\
$\mathrm{O}_{3}$ & 1.53 \\
Radicals $\left(\mathrm{HO}_{2}+\mathrm{NO}_{3}\right)$ & 0.81 \\
$\mathrm{H}_{2}$ & 0.60 \\
$\mathrm{HNO}_{\mathrm{y}}$ & 0.15 \\
Total Inorganic & 47.76 \\
VOC & \\
CH & \\
Hydrocarbons & 1.85 \\
Aldehydes, and other hydrocarbon products & 14.50 \\
Total Organic & 35.89 \\
\hline
\end{tabular}

Different classes of VOC contribute differently to the loss of $\mathrm{HO}^{*}$, Figure 19. Figure 19 shows the relative fraction of $\mathrm{HO}^{\circ}$ that react with each class of $\mathrm{VOC}$ at noon on the second simulated day. By the second day aldehydes and ketones are the most important organic sink of $\mathrm{HO}^{\circ}$. They are among the first generation of oxidation products and highly reactive with respect to $\mathrm{HO}^{\circ}$.

Figure 19. This figure shows the relative fraction of $\mathrm{HO}^{\circ}$ that react with each class of VOC for the polluted urban atmosphere case. The time for the plot is noon on the second simulated day.

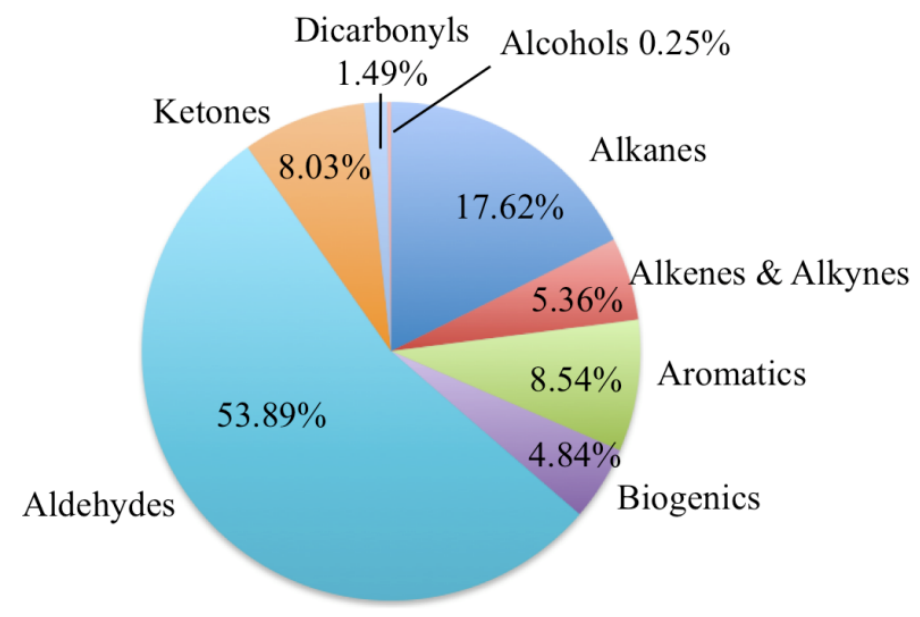


The mixing ratios for the organic peroxy radicals produced from the oxidation of VOC are shown in Figure 20. In this case the peroxy radicals produced from alkenes was very high initially but their production dropped relatively quickly. For most of the simulation the peroxy radicals produced from alkanes, methyl peroxy radical $\left(\mathrm{CH}_{3} \mathrm{O}_{2}\right)$ and acyl peroxy radicals $\left(\mathrm{RCO}_{3}\right)$ had the highest mixing ratios.

Figure 20. The mixing ratios of organic peroxy radicals by organic class are shown for the polluted urban atmosphere case.

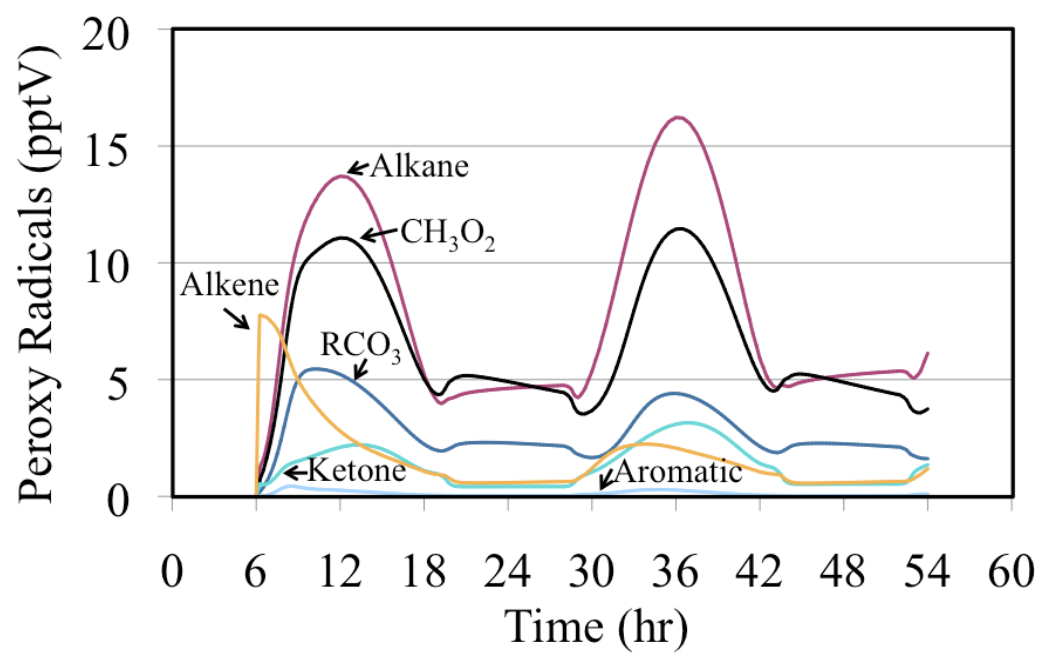

The mixing ratios of $\mathrm{HO}_{2}{ }^{\circ}$ radicals and the total mixing ratios of the organic peroxy radicals are shown in Figure 21. Both profiles peak near noon with the $\mathrm{HO}_{2}{ }^{\circ}$ radicals having the highest daytime mixing ratios while the total mixing ratio of the organic peroxy radicals having the highest nighttime value. The high nighttime organic peroxy radical mixing ratios are produced through the reactions of $\mathrm{O}_{3}$ and $\mathrm{NO}_{3}$ with aldehydes and alkenes.

Figure 21. The mixing ratio of $\mathrm{HO}_{2}{ }^{\circ}$ and the total mixing ratio of organic peroxy radicals are shown for the polluted urban atmosphere case.

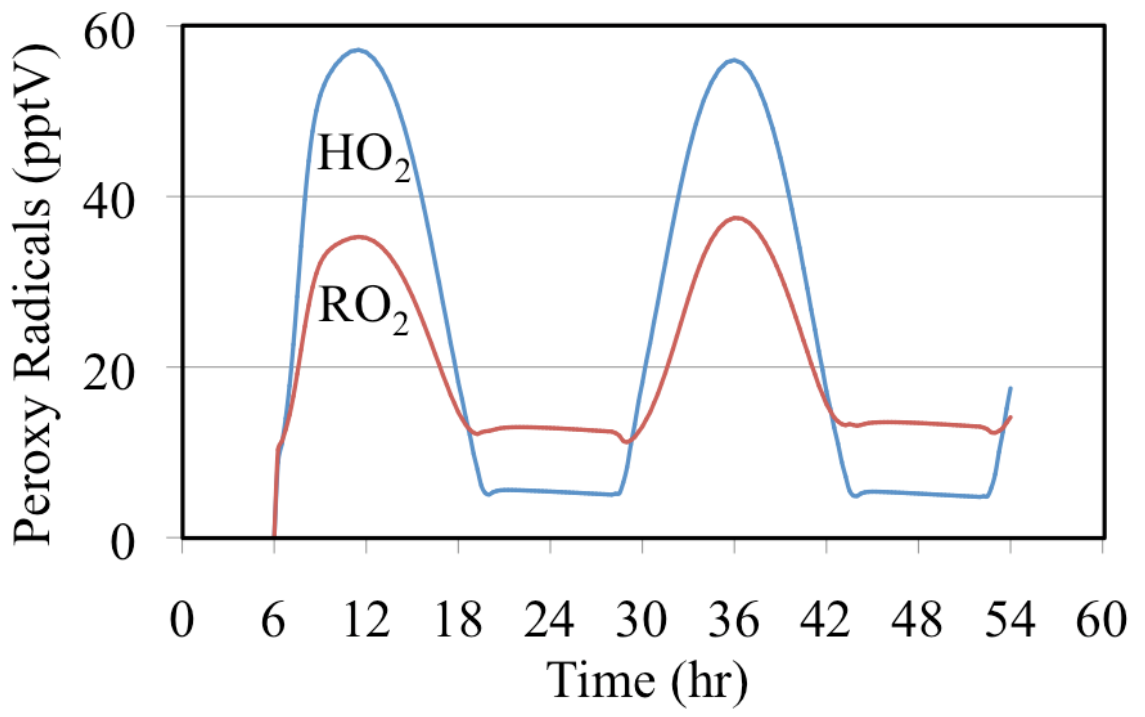


The initial atmosphere was assumed to be $\mathrm{NO}_{2}$ and NO, Figure 22. These were rapidly converted to a mixture that also included organic nitrates, peroxyactyl nitrates and $\mathrm{HNO}_{3}$.

Figure 22. The time dependent fate of the nitrogen containing species is shown as a stack plot for the polluted urban atmosphere case.

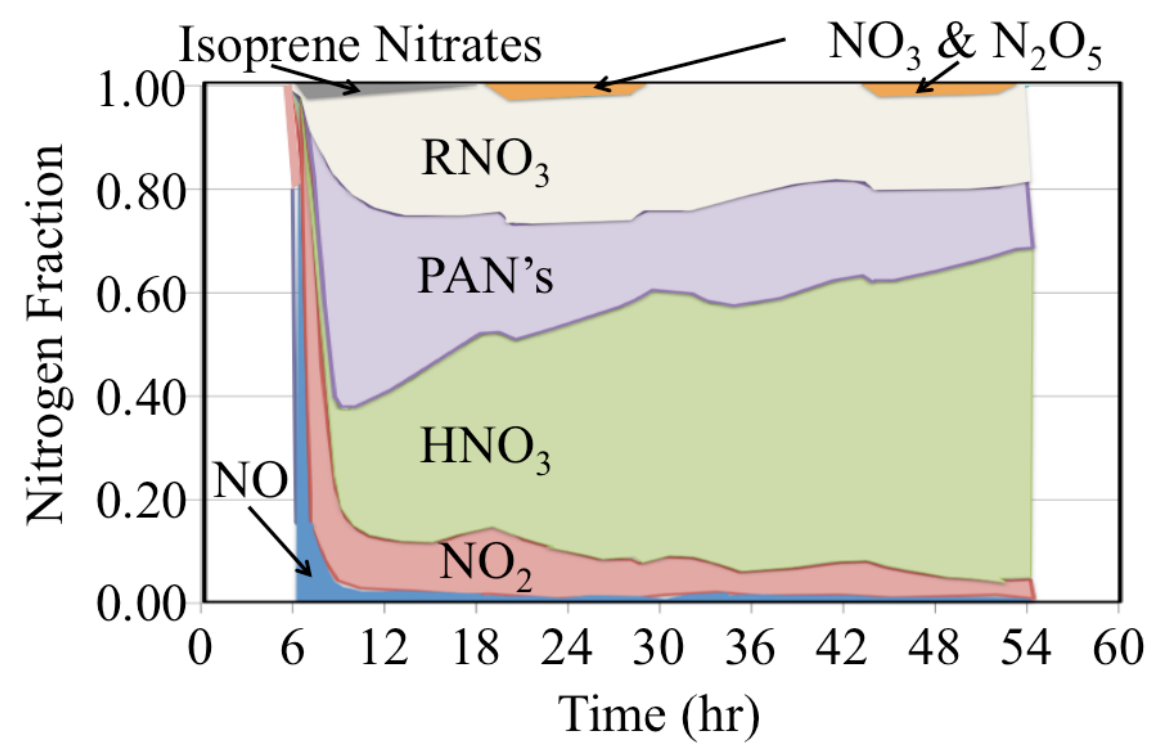

Organic nitrates are produced from the reaction of organic peroxy radicals with NO, Reaction 65.

$$
\mathrm{RO}_{2}{ }^{\circ}+\mathrm{NO} \rightarrow \mathrm{RNO}_{3}
$$

The yield of organic nitrates tends to increase for higher molecular weight organic peroxy radicals [45]. The peroxyactyl nitrates were produced from the reaction of acetyl peroxy radicals with $\mathrm{NO}_{2}$. There is strong production of $\mathrm{HNO}_{3}$ during the day and nighttime. However the $\mathrm{HNO}_{3}$ production rate is somewhat slower at sunrise and sunset due to the lower concentrations of $\mathrm{HO}^{\circ}$ or $\mathrm{NO}_{3}$ radicals during these times. The figure shows that over the long term of the simulation that nitrogen oxide emissions are converted to $\mathrm{HNO}_{3}$ and organic nitrates.

In summary of this section, the polluted urban atmosphere simulation showed that there is a complex interplay between the daytime and nighttime chemistry induced by the $\mathrm{HO}^{\circ}$ and $\mathrm{NO}_{3}$ radicals, respectively. Both of these radicals react to convert $\mathrm{NO}_{\mathrm{x}}$ to $\mathrm{HNO}_{3}$ while oxidizing organic compounds. The nighttime reactions of $\mathrm{O}_{3}$ and $\mathrm{NO}_{3}$ with aldehydes and alkenes produced $\mathrm{HO}^{\circ}, \mathrm{HO}_{2}{ }^{\circ}$ and organic peroxy radical production during the night.

The loss of $\mathrm{NO}_{x}$ reduces $\mathrm{O}_{3}$ formation because it is the photolysis of $\mathrm{NO}_{2}$ that leads to the production of $\mathrm{O}_{3}$. While the mixture began with $\mathrm{NO}$ and $\mathrm{NO}_{2}$ as the only reactive nitrogen containing species as the air aged these were converted to $\mathrm{HNO}_{3}$ and organic nitrates. The loss of $\mathrm{NO}_{\mathrm{x}}$ was somewhat underestimated in this gas-phase simulation because the heterogeneous conversion of $\mathrm{N}_{2} \mathrm{O}_{5}$ to $\mathrm{HNO}_{3}$ was not included. Dry and wet depositions of $\mathrm{HNO}_{3}$ are very significant sinks for atmospheric nitrogen but these were not included in our simulations. In addition, sulfate, hydrogen peroxide and organic peroxides are removed from the atmosphere through deposition.

The daytime formaldehyde photolysis was a more important source of $\mathrm{HO}^{*}$ radicals than $\mathrm{O}_{3}$ photolysis during the early morning and late afternoon hours and as the air aged aldehydes and ketones 
became the most important organic sink of $\mathrm{HO}^{\bullet}$ radicals. The reaction of $\mathrm{HO}^{\bullet}$ with $\mathrm{VOC}$ produced organic peroxy radicals, while peroxy radicals with the highest mixing ratios were radicals produced from alkanes, the methyl peroxy radical $\left(\mathrm{CH}_{3} \mathrm{O}_{2}{ }^{\circ}\right)$ and acyl peroxy radicals $\left(\mathrm{RCO}_{3}{ }^{\circ}\right)$.

\subsection{The Effect of Temperature on Ozone Formation}

High ozone pollution episodes are associated with stagnant high-pressure systems. Stagnant highs are associated with clear days and strong temperature inversions. These conditions lead to higher photolysis rates, low mixing heights and higher surface temperatures [52]. Higher temperatures increase evaporation rates increasing VOC emissions.

All of these cofactors increase the production of $\mathrm{O}_{3}$. Greater photolysis rates and increased emissions are likely to have the most significant effects that lead to increases in $\mathrm{O}_{3}$ production. However the effect of temperature on the rates of chemical reactions is not insignificant. Temperature has a strong effect on the rate constant of most reactions. For example, the Arrhenius Equation, 66, is one of the most important equations that characterize the temperature dependence for many reactions.

$$
k=A \exp \left(\frac{-E_{a}}{R T}\right)
$$

In Equation 66, $A$ is the pre-exponential factor, $E_{a}$ is the activation energy per mole, $R$ is the ideal gas constant and $T$ is the temperature. For most reactions the activation energy is positive; if $E_{a}$ is positive than the rate constant of the reaction increases with temperature. The polluted urban case was run for temperatures of 296, 298 and $300 \mathrm{~K}$ to explore the effect of temperature in the absence of other factors. Figure 23 shows the maximum $\mathrm{O}_{3}$ on the first day. For this case the response of the maximum $\mathrm{O}_{3}$ to temperature is very linear $\left(R^{2}=0.999\right)$ and the slope of the best-fit line for this case is $4.3 \mathrm{ppb} \mathrm{K}^{-1}$.

Figure 23. Maximum $\mathrm{O}_{3}$ mixing ratios on the first day as a function of temperature for the polluted urban atmosphere case.

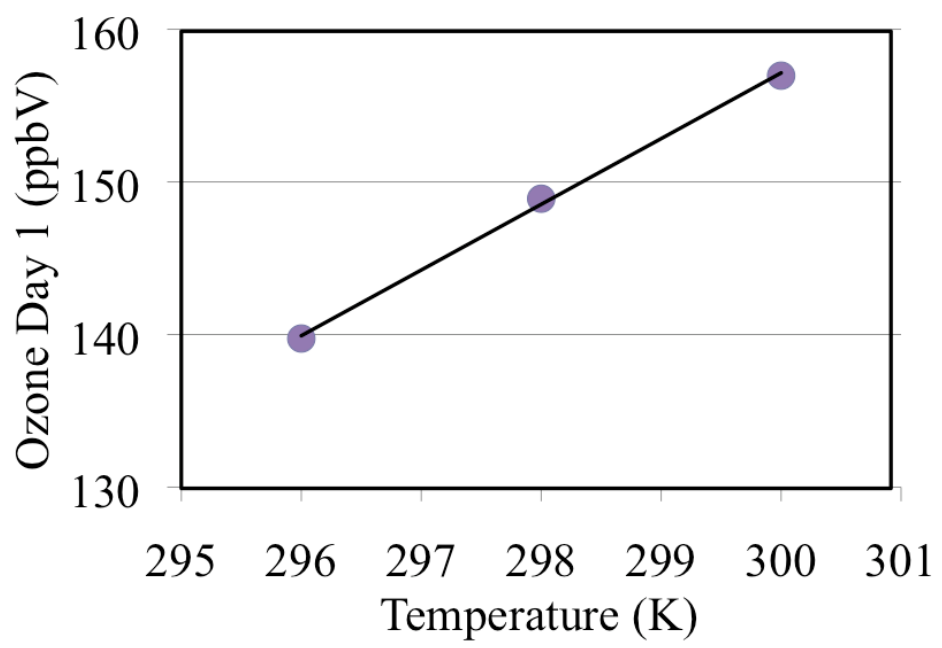

Increasing temperatures due to climate change are likely to make the abatement of tropospheric $\mathrm{O}_{3}$ more difficult due to all of these factors. 


\section{Major Uncertainties and New Research Needs}

The gas-phase production of $\mathrm{O}_{3}$ and particles is initiated by photolysis and involves a complex series of reactions. Some of the greatest uncertainties involve the temperature dependence of gas phase reactions for both inorganic and organic species. These uncertainties affect any model's ability to predict upper tropospheric as well as nighttime chemistry and composition. Nighttime chemistry requires attention as it affects multi-day modeling scenarios, while upper tropospheric chemistry affects long range transport of pollutants such as $\mathrm{PAN}$ and $\mathrm{O}_{3}$ which are typically simulated using global models [53-55].

More specifically, knowledge of organic peroxy radical $+\mathrm{HO}_{2}{ }^{\circ}$ rate constants is needed as well as their product information (not all of these reactions lead to peroxide formation). The reaction rates of peroxy radicals with $\mathrm{NO}$ and $\mathrm{NO}_{3}$ are largely estimated, and their temperature dependence is not known. The importance of peroxy- $\mathrm{NO}_{3}$ reactions grows during the nighttime hours. If the degree of oxidation by $\mathrm{NO}_{3}$ is not predicted correctly, than the $\mathrm{VOC} / \mathrm{NO}_{\mathrm{x}}$ ratio at sunrise will be affected, which impacts multi-day modeling.

Other reactions for which the temperature dependence is not known are: glyoxal $+\mathrm{NO}_{3}$, methyl glyoxal $+\mathrm{NO}_{3}$, propanal $+\mathrm{NO}_{3}$ and formaldehyde $+\mathrm{NO}_{3}$. Another reaction which requires attention is the equilibrium reaction of PPN that is assumed currently to be the same as PAN.

The photolysis of higher organic peroxides $\left(\mathrm{C}_{2}\right.$ and greater $)$ is currently assumed to be the same as methyl hydroperoxide. Aromatic degradation schemes are largely parameterized, and knowledge of reactions of their second generation products is needed. Much remains to learn about the products of the oxidation of biologically emitted compounds, including isoprene [9,56]. Finally the relative importance of halogen chemistry in the production of troposphric ozone is an important topic that requires further investigation.

\section{Conclusions}

The gas-phase production of air pollutants is initiated by photolysis and involves a complicated series of free radical reactions. During the nighttime the reaction of $\mathrm{O}_{3}$ with alkenes and $\mathrm{NO}_{2}$ also leads to the production of free radicals. There are a very high number of chemical compounds emitted into the atmosphere. Tens of thousands of compounds react through millions of reactions. In comparison a relatively small number of reactions have been studied with their rate constants known (for room temperature) much better than their product yields. The knowledge base is very incomplete relative to the complex nature of atmospheric chemistry.

There are severe computational limitations on the size of a chemical mechanism that can be used for air quality modeling. Air quality models with high spatial resolution have tens of thousands of grid boxes and therefore each prognostic chemical species included in the model adds tens of thousands of differential equations to solve and much additional memory storage. The chemical mechanism used in a meteorological air quality model must be very simple in contrast to real atmospheric chemistry.

There are several chemical mechanisms that have been developed for air quality modeling. More data from the laboratory, environmental reaction chamber and field are required to improve atmospheric 
chemical mechanisms. It is very possible that there are major surprises to be discovered especially in the chemistry of $\mathrm{HO}_{\mathrm{x}}$ and other processes that control $\mathrm{O}_{3}$ and particle formation [57].

\section{Acknowledgments}

The authors thank the late Daewon Byun for helping to conceive this paper. The authors thank the National Science Foundation for grant number 0653997, “Collaborative Research: Nitrate $\left(\mathrm{NO}_{3}\right)$ Induced Nighttime Air Chemistry" that partially funded this research. The authors thank the National Aeronautics and Space Administration for supporting Ms. Lawson under its grant "Howard University Beltsville Center for Climate System Observation". Additional support was provided by the California Air Resources Board and the U.S. Environmental Protection Agency (through Oak Ridge Institute for Science and Engineering) and a grant from the National Oceanic and Atmospheric Administration to Howard University's NOAA Center for Atmospheric Sciences. We thank the reviewers for many useful comments. The opinions expressed in this publication are those of the authors alone and do not reflect the policy of any governmental agency.

\section{References}

1. Demerjian, K.L.; Kerr, J.A.; Calvert, J.G. The Mechanism of Photochemical Smog Formation. In Advances in Environmental Science and Technology; Wiley: New York, NY, USA, 1974; Volume 4.

2. Calvert, J.G.; Stockwell, W.R. Acid generation in the troposphere by gas phase chemistry. Environ. Sci. Technol. 1983, 17, 428A-443A.

3. Finlayson-Pitts, B.J.; Pitts, J.N., Jr. Chemistry of the Upper and Lower Atmosphere; Academic Press: San Diego, CA, USA, 1999.

4. Seinfeld, J.H.; Pandis, S. Atmospheric Chemistry and Physics from Air Pollution to Climate Change; John Wiley \& Sons: New York, NY, USA, 1998.

5. Jenkin, M.E.; Saunders S.M.; Pilling, M.J. The tropospheric degradation of volatile organic compounds: A protocol for mechanism development. Atmos. Environ. 1997, 31, 81-104.

6. Geiger, H.; Barnes, I.; Becker, K.H.; Bohn, B.; Brauers, T.; Donner, B.; Dorn, H.-P.; Elend, M.; Dinis, C.M.F.; Grossmann, D.; et al. Chemical mechanism development: Laboratory studies and model applications. J. Atmos. Chem. 2002, 42, 323-357.

7. Sander, S.P.; Abbatt, J.; Barker, J.R.; Burkholder, J.B.; Friedl, R.R.; Golden, D.M.; Huie, R.E.; Kolb, C.E.; Kurylo, M.J.; Moortgat, G.K.; et al. Chemical Kinetics and Photochemical Data for Use in Atmospheric Studies, Evaluation Number 16, Supplement to Evaluation 15: Update of Key Reactions; NASA Jet Propulsion Laboratory: Pasadena, CA, USA, 2010.

8. International Union of Pure and Applied Chemistry Subcommittee for Gas Kinetic Data Evaluation. Evaluated Kinetic Data, 2008. Available online: http://www.iupac-kinetic.ch.cam.ac.uk/ (accessed on 24 October 2011).

9. Fuentes, J.D.; Lerdau, M.; Atkinson, R.; Baldocchi, D.; Botteneheim, J.W.; Ciccioli, P.; Lamb, B.; Geron, C.; Gu, L.; Guenther, A.; et al. Biogenic hydrocarbons in the atmospheric boundary layer: A review. Bull. Amer. Meteor. Soc. 2000, 81, 1537-1575. 
10. Simon, H.; Beck, L.; Bhave, P.V.; Divita, F.; Hsu, Y.; Luecken, D.; Mobley, J.D.; Pouliot, G.A.; Reff, A.; Sarwar, G.; et al. The development and uses of EPA's SPECIATE database. Atmos. Pollut. Res. 2010, 1, 196-206.

11. Madronich, S.; Calvert, J.G. The NCAR Master Mechanism of the Gas Phase Chemistry-Version 2.0; NCAR/TN-333+SRT; NCAR: Boulder Colorado, CO, USA, 1990.

12. Master Chemical Mechanism, version 3.1. Available online: http://www1.chem.leeds.ac.uk// Atmospheric/MCM/mcmproj.html (accessed on 24 October 2011).

13. Szopa, S.; Aumont, B.; Madronich, S. Assessment of the reduction methods used to develop chemical schemes: Building of a new chemical scheme for VOC oxidation suited to three-dimensional multiscale $\mathrm{HO}_{\mathrm{x}}-\mathrm{NO}_{\mathrm{x}}$-VOC chemistry simulations. Atmos. Chem. Phys. 2005, 5, 2519-2538.

14. Crutzen, P.J. My Life with $\mathrm{O}_{3}, \mathrm{NO}_{\mathrm{x}}$ and Other $\mathrm{YZO}_{\mathrm{xs}}$; Nobel Lecture; 8 December 1995. Available online: http://www.nobelprize.org/nobel_prizes/chemistry/laureates/1995/crutzenlecture.html (accessed on 24 October 2011).

15. Jenkin, M.E.; Watson, L.A.; Utembe, S.R.; Shallcross, D.E. A common representative intermediates (CRI) mechanism for VOC degradation. Part 1: Gas phase mechanism development. Atmos. Environ. 2008, 42, 7185-7195.

16. Watsona, L.A.; Shallcrossa, D.E.; Utembea, S.R.; Jenkinb, M.E. A Common Representative Intermediates (CRI) mechanism for VOC degradation. Part 2: Gas phase mechanism reduction. Atmos. Environ. 2008, 42, 7196-7204.

17. Byun, Q.W.; Ching, J.K.S. Science Algorithms of the EPA Models-3 Community Multiscale Aie Quality (CMAQ) Modeling System; EPA Report EPA-600/R-89-030; U.S. Environmental Protection Agency: Washington, DC, USA, 1999.

18. Jacobson, M.Z. Fundamentals of Atmospheric Modeling; Cambridge University Press: Cambridge, UK, 1999.

19. Makar, P.A.; Stockwell, W.R.; Li, S.-M. Gas-phase chemistry mechanisms compression strategies: Treatment of reactants. Atmos. Environ. 1996, 30, 831-842.

20. Proceedings of the Empirical Kinetics Modeling Approach (EKMA) Validation Workshop; EPA Report EPA-600/9-83-014; Dimitriades, B., Dodge, M., Eds.; Environmental Sciences Research Lab: Research Triangle Park, NC, USA, 1983.

21. Stockwell, W.R.; Middleton, P.; Chang, J.S.; Tang, X. The second generation regional acid deposition model chemical mechanism for regional air quality modeling. J. Geophys. Res. 1990, 95, 16343-16367.

22. Whitten, G.Z.; Hogo, H. Mathematical Modeling of Simulated Photochemical Smog; EPA Report EPA-600/3-77-011; Environmental Protection Agency: Washington, DC, USA, 1999.

23. Whitten, G.Z.; Hogo, H.; Killus, J.P. The carbon-bond mechanism: A condensed kinetic mechanism for photochemical smog. Environ. Sci. Technol. 1980, 14, 690-700.

24. Yarwood, G.; Rao, S.; Yocke, M.; Whitten, G. Updates to the Carbon Bond Chemical Mechanism: CB05. Final Report to the US EPA; EPA Report RT-0400675, 2005. Available online: http://www.camx.com/publ/pdfs/CB05_Final_Report_120805.pdf (accessed on 24 October 2011). 
25. Gery, M.W.; Whitten, G.Z.; Killus, J.P.; Dodge, M.C. A photochemical mechanism for urban and regional scale computer modeling. J. Geophys. Res. 1989, 94, 12925-12956.

26. Kim, Y.; Sartelet, K.; Seigneur, C. Formation of secondary aerosols over Europe: Comparison of two gas-phase chemical mechanisms. Atmos. Chem. Phys. 2011, 11, 583-598.

27. Stockwell, W.R.; Kirchner, F.; Kuhn, M.; Seefeld, S. A new mechanism for regional atmospheric chemistry modeling. J. Geophys. Res. 1997, 102, 25847-25879.

28. Carter, W.P.L. Development of the SAPRC-07 chemical mechanism. Atmos. Environ. 2010, 44, 5324-5335.

29. Carter, W.P.L. A detailed mechanism for the gas-phase atmospheric reactions of organic compounds. Atmos. Environ. 1990, 24A, 481-518.

30. Carter, W.P.L. Documentation of the SAPRC-99 Chemical Mechanism for VOC Reactivity Assessment. Final Report to California Air Resources Board Contract No. 92-329, and 95-308; California Environmental Protection Agency, Air Resources Board, Research Division: Sacramento, CA, USA, 2000.

31. Goliff, W.S.; Stockwell, W.R. The Regional Atmospheric Chemistry Mechanism, Version 2, an Update. In Proceedings of the International Conference on Atmospheric Chemical Mechanisms; University of California, Davis, CA, USA, 8-10 December 2008; University of California: Davis, CA, USA, 2008.

32. Middleton, P.; Stockwell, W.R.; Carter, W.P.L. Aggregation and analysis of volatile organic compound emissions for regional modeling. Atmos. Environ. 1990, 24A, 1107-1133.

33. Seefeld, S.; Stockwell, W.R. First-order sensitivity analysis of models with time dependent parameters: An application to PAN and ozone. Atmos. Environ. 1999, 33, 2941-2953.

34. Madronich, S. Photodissociation in the atmosphere; 1. actinic flux and the effects on ground reflections and clouds. J. Geophys. Res. 1987, 92, 9740-9752.

35. Warneck, P. Chemistry of the Natural Atmosphere, 2nd ed.; Academic Press: San Diego, CA, USA, 1999.

36. Calvert, J.G.; Stockwell, W.R. Deviations from the $\mathrm{O}_{3}-\mathrm{NO}-\mathrm{NO}_{2}$ photostationary state in tropospheric chemistry. Can. J. Chem. 1983, 61, 983-992.

37. Horie, O.; Moortgat, G.K. Decomposition pathways of the excited Criegee intermediates in the ozonolysis of simple alkenes. Atmos. Environ. 1991, 25A, 1881-1896.

38. Atkinson R.; Aschmann, S.M. OH radical production from the gas-phase reactions of $\mathrm{O}_{3}$ with a series of alkenes under atmospheric conditions. Environ. Sci. Technol. 1993, 27, 1357-1363.

39. Atkinson, R.; Tuazon, E.C.; Aschmann, S.M. Products of the gas-phase reactions of $\mathrm{O}_{3}$ with alkenes. Environ. Sci. Technol. 1995, 29, 1860-1866.

40. Calvert, J.G.; Atkinson, A.; Becker, K.H.; Kamens, R.M.; Seinfeld, J.H.; Wallington, T.J.; Yarwood, G. The Mechanisms of Atmospheric Oxidation of Aromatic Hydrocarbons; Oxford University Press: Oxford, UK, 2002.

41. Bloss, C.; Wagner, V.; Bonzanini, A.; Jenkin, M.E.; Wirtz, K.; Martin-Reviejo, M.; Pilling, M.J. Evaluation of detailed aromatic mechanisms (MCMv3 and MCMv3.1) against environmental chamber data. Atmos. Chem. Phys. 2005, 5, 623-639.

42. Berndt, T.; Böge, O. Formation of phenol and carbonyls from the atmospheric reaction of $\mathrm{OH}$ radicals with benzene. Phys. Chem. Chem. Phys. 2006, 8, 1205-1214. 
43. Gomez Alvarez, E.G.; Viidanoja, J.; Munoz, A.; Wirtz, K.; Hjorth, J. Experimental confirmation of the dicarbonyl route in the photo-oxidation of toluene and benzene. Environ. Sci. Technol. 2007, 41, 8362-8369.

44. Atherton, C.; Penner, J. The effects of biogenic hydrocarbons on the transformation of nitrogen oxides in the troposphere. J. Geophys. Res. 1990, 95, doi:10.1029/JD095iD09p14027.

45. Atkinson, R. Atmospheric chemistry of VOCs and $\mathrm{NO}_{\mathrm{x}}$. Atmos. Environ. 2000, 34, 2063-2101.

46. Stockwell, W.R.; Calvert, J.G. The mechanism of $\mathrm{NO}_{3}$ and $\mathrm{HONO}$ formation in the nighttime chemistry of the urban atmosphere. J. Geophy. Res. 1983, 88, 6673-6682.

47. Cantrell, C.A.; Stockwell, W.R.; Anderson, L.G.; Busarow, K.L.; Perner, D.; Schmeltekope, A.; Calvert, J.G.; Johnston, H.S. Kinetic study of the $\mathrm{NO}_{3}-\mathrm{CH}_{2} \mathrm{O}$ reaction and its possible role in nighttime tropospheric chemistry. J. Phys. Chem. 1985, 89, 139-146.

48. Stockwell, W.R. On the $\mathrm{HO}_{2}+\mathrm{HO}_{2}$ reaction: Its misapplication in atmospheric chemistry models. J. Geophys. Res. 1995, 100, 11695-11698.

49. Villenave, E.; Lesclaux, R.; Seefeld, S.; Stockwell, W.R. Kinetics and atmospheric implications of peroxy radical cross reactions involving $\mathrm{CH}_{3} \mathrm{C}(\mathrm{O}) \mathrm{O}_{2}$ radical. J. Geophys. Res. 1998, 103, 25273-25285.

50. Kirchner, F.; Stockwell, W.R. Effect of peroxy radical reactions on the predicted concentrations of ozone, nitrogenous compounds and radicals. J. Geophys. Res. 1996, 101, 21007-21022.

51. Stockwell, W.R.; Calvert, J.G. The mechanism of the $\mathrm{HO}-\mathrm{SO}_{2}$ reaction. Atmos. Environ. 1983, 17, 2231-2235.

52. Lu, R.; Turco, R.P.; Jacobson, M.Z. An integrated air pollution modeling system for urban and regional scales: 2. Simulations for SCACS 1987. J. Geophys. Res. 1997, 102, 6081-6098.

53. Henderson, B.H.; Pinder, R.W.; Crooks, J.; Cohen, R.C.; Wennberg, P.O.; Hutzell, W.T.; Sarwar, G.; Goliff, W.S.; Stockwell, W.R.; Fahr, A.; et al. Evaluation of simulated photochemical partitioning of oxidized nitrogen in the upper troposphere. Atmos. Chem. Phys. 2011, 11, 275-291.

54. Crowley, J.N.; Schuster, G.; Pouvesle, N.; Bonn, B.; Bingemer, H.; Parchatka, U.; Fischer, H.; Lelieveld, J. Nocturnal nitrogen oxides at a rural mountain-site in Southwestern Germany. Atmos. Chem. Phys. 2010, 10, 2795-2812.

55. Emmerson, K.M.; Evans, M.J. Comparison of tropospheric gas-phase chemistry schemes for use within global models. Atmos. Chem. Phys. 2009, 9, 1831-1845.

56. Galloway, M.M.; Huisman, A.J.; Yee, L.D.; Chan, A.W.H.; Loza, C.L.; Seinfeld, J.H.; Keutsch, F.N. Yields of oxidized volatile organic compounds during the $\mathrm{OH}$ radical initiated oxidation of isoprene, methyl vinyl ketone, and methacrolein under high- $\mathrm{NO}_{\mathrm{x}}$ conditions. Atmos. Chem. Phys. 2011, 11, 10779-10790.

57. Chen, S.; Ren, X.; Mao, J.; Chen, Z.; Brune, W.H.; Lefer, B.; Rappenglück, B.; Flynn, J.; Olson, J.; Crawford, J.H. A comparison of chemical mechanisms based on TRAMP-2006 field data. Atmos. Environ. 2010, 44, 4116-4125.

(C) 2012 by the authors; licensee MDPI, Basel, Switzerland. This article is an open access article distributed under the terms and conditions of the Creative Commons Attribution license (http://creativecommons.org/licenses/by/3.0/). 